\title{
GROWTH FORMS AND COMPOSITION OF CHROMIAN SPINEL IN MORB MAGMA: DIFFUSION-CONTROLLED CRYSTALLIZATION OF CHROMIAN SPINEL
}

\author{
PETER L. ROEDER ${ }^{\S}$ AND ALEXEI POUSTOVETOV \\ Department of Geological Sciences and Geological Engineering, Queen's University, Kingston, Ontario K7L 3N6, Canada
}

NIELS OSKARSSON

Nordic Volcanological Institute, Reykjavik, Iceland

\begin{abstract}
Microphenocrysts of chromian spinel in glass from an East Pacific Rise lava and three Icelandic subglacial lavas show a variety of complex skeletal, hopper, vermiform and chain textures. These grains of chromian spinel are larger than those found in most basalts. Many crystals show significant zoning in $\mathrm{Cr} /(\mathrm{Cr}+\mathrm{Al})$, and the variation in $\mathrm{Cr} /(\mathrm{Cr}+\mathrm{Al})$ with respect to $\mathrm{Fe}^{2+} /\left(\mathrm{Fe}^{2+}\right.$ $+\mathrm{Mg}$ ) is distinctive for each sample. The four samples are relatively primitive, with between 9 and $10 \mathrm{wt} \% \mathrm{MgO}$ in the glass. One very distinctive texture, a core surrounded by a vermiform rim, has been interpreted by a number of researchers as a reaction texture caused either by changes in pressure or magma mixing. The variety of chromian spinel textures, including the vermiform rim, has been duplicated in an experimental run using the sample from the East Pacific Rise. The sample was held at $1225^{\circ} \mathrm{C}$ for 67 hours and then cooled slowly over 8 hours to $1147^{\circ} \mathrm{C}$. We conclude that the vermiform texture and the other chromian spinel textures in the experimental run and the lavas are growth textures and not reaction textures. The change in growth habit that produces the vermiform rim is interpreted as diffusion-controlled growth, leading to what metallurgists refer to as cellular growth. Chromian spinel is susceptible to diffusion-controlled growth because of the very large difference in concentration of $\mathrm{Cr}$ in the melt $\left(0.02-0.06\right.$ wt. $\left.\% \mathrm{Cr}_{2} \mathrm{O}_{3}\right)$ and in chromian spinel $\left(30-50 \mathrm{wt} . \% \mathrm{Cr}_{2} \mathrm{O}_{3}\right)$ at equilibrium. Although the chromian spinel in the glass of each natural sample shows a large variation in $\mathrm{Cr} /(\mathrm{Cr}+\mathrm{Al})$, and thus was not in equilibrium with the bulk melt, its $\mathrm{Fe}^{2+} /$ $\left(\mathrm{Fe}^{2+}+\mathrm{Mg}\right)$ may have been close to equilibrium with the bulk melt before quenching. The chromian spinel crystallized over a span of hours to days before a rapid water quench upon eruption. The complex textures and zoning probably reflect the turbulent conditions during passage of the magma toward the Earth's surface.
\end{abstract}

Keywords: chromian spinel, chromite, basalt, texture, vermiform, hopper, diffusion-controlled crystallization.

\section{SOMMAIRE}

Des microphénocristaux de spinelle chromifère sont présents dans une matrice vitreuse d'une lave basaltique provenant de la ride Est-Pacifique et de trois échantillons de coulées mises en place sous un glacier en Icelande. Ces cristaux contiennent une variété de textures complexes en entonnoir, vermiformes et en chaînes; ils sont plus grossiers que ceux qui caractérisent la plupart des basaltes. Plusieurs cristaux montrent une zonation importante en $\mathrm{Cr} /(\mathrm{Cr}+\mathrm{Al})$, qui varie de façon distincte avec $\mathrm{Fe}^{2+} /\left(\mathrm{Fe}^{2+}+\right.$ $\mathrm{Mg}$ ) dans chaque échantillon. Les quatre échantillons sont relativement primitifs, le verre contenant entre 9 et $10 \%$ (poids) de $\mathrm{MgO}$. On a généralement interprété la présence d'un coeur entouré d'un liseré vermiforme comme résultat d'une réaction suite à des changements en pression ou à un mélange de magmas. La diversité texturale du spinelle chromifère, y inclus la bordure vermiforme, a été reproduite dans un série d'expériences faites avec le basalte de la ride Est-Pacifique. Nous avons maintenu l'échantillon à $1225^{\circ} \mathrm{C}$ pour 67 heures, et nous l'avons refroidi lentement sur huit heures jusqu'à $1147^{\circ} \mathrm{C}$. A notre avis, la texture vermiforme et les autres développements texturaux dans les résultats d'expériences et dans les laves résultent de la croissance et non d'une réaction. Le changement en morphologie qui mène à la bordure vermiforme résulterait d'une croissance régie par la diffusion, menant à ce que les métallurgistes appelent une croissance cellulaire. Le spinelle chromifère est susceptible de croître par un mécanisme régi par la diffusion à cause de la très grande différence en concentration de $\mathrm{Cr}$ dans le liquide silicaté $(0.02-$ $0.06 \% \mathrm{Cr}_{2} \mathrm{O}_{3}$, poids) et le spinelle chromifère (30-50\% $\left.\mathrm{Cr}_{2} \mathrm{O}_{3}\right)$ à l'équilibre. Quoique le spinelle encaissé dans la matrice vitreuse de chaque échantillon fait preuve de variations importantes en $\mathrm{Cr} /(\mathrm{Cr}+\mathrm{Al})$, et donc ne serait pas en équilibre avec le liquide à grande échelle, la valeur du rapport $\mathrm{Fe}^{2+} /\left(\mathrm{Fe}^{2+}+\mathrm{Mg}\right)$ semble être proche de l'équilibre avant le refroidissement final de l'assemblage. Le spinelle chromifère s'est formé sur un intervalle de quelques heures à quelques jours avant que les laves aient été trempées dans l'eau à l'éruption. Les textures complexes et la zonation témoignent probablement des conditions turbulentes au cours du passage du magma vers la surface d'épanchement.

(Traduit par la Rédaction)

Most-clés: spinelle chromifère, chromite, basalte, texture, vermiforme, entonnoir, cristallisation régie par diffusion.

§ E-mail address: roeder@geol.queensu.ca 


\section{INTRODUCTION}

Chromian spinel and olivine are generally the first phases to crystallize from basaltic lavas. Chromian spinel is usually found as small octahedra of 5-20 $\mu \mathrm{m}$ or as clusters of crystals within or associated with olivine phenocrysts (Fig. 1a). Some of these clusters (Fig. 1b) contain octahedra of chromian spinel that are oriented with respect to each other to form chains (Wilcox 1954, Dick \& Bryan 1978, Bannister et al. 1998). The growth forms of chromian spinel in Figure 1 are typical of basaltic and some andesitic lavas from varied tectonic regimes. The microphenocrysts found within olivine phenocrysts and in glass matrices are usually euhedral, whereas the crystals of chromian spinel found in the groundmass of lava flows, such as at Paricutín (Bannister et al. 1998), are commonly larger, and either subhedral or anhedral, owing to continued growth upon cooling of the lava flow.

A very distinctive texture involving chromian spinel (Fig. 2) has been found in a number of basaltic lavas. A core of chromian spinel is surrounded by a vermiform rim that has usually been interpreted (e.g., Dick \& Bryan 1978, Graham et al. 1979, Fisk \& Bence 1980, Allan et al. 1988, 1996, Natland 1989) as due to resorption or reaction of an earlier-formed chromian spinel with melt. Implications of such an interpretation are that the core of the chromian spinel has crystallized in one chemical or physical environment, and that a significant change in environment has caused the chromian spinel to react with a different melt, thus producing the vermiform texture in the rim. Allan et al. (1988) also suggested that rapid growth of chromian spinel could lead to local depletion in $\mathrm{Cr}$. Since this vermiform texture has been noted in lavas from many diverse localities, including the Cascades (Brandon \& Draper 1996), the Costa Rica Rift (Furuta \& Tokuyama 1983), the Mid-Atlantic Rift (Bryan \& Moore 1977, Dick \& Bryan 1978, Fisk \& Bence 1980) and the Lamont chain of seamounts in the eastern Pacific (Allan et al. 1988), the process that has led to this texture must be fairly common.

The presence of skeletal and complex growth-forms of chromian spinel have also been reported in plutonic rocks. Greenbaum (1977) described large dendritic crystals either in isolation or within nodules of chromian spinel in podiform chromitites of the Troodos ophiolite complex in Cyprus. Christiansen \& Olesen (1990) also reported dendritic chromian spinel from the Vourinos ophiolite in Greece. These dendritic and skeletal crystals are much larger than those found in volcanic samples, but many of the shapes are similar. Both Greenbaum (1977) and Christiansen \& Olesen (1990) concluded that the skeletal nature of the chromian spinel was due to a magmatic process.

The crystallization of chromian spinel from basaltic magma has a very small influence on the composition of the melt because of the small amount that crystallizes from that melt. It has been suggested (Irvine 1965,
Dick \& Bullen 1984, Roeder 1994) that the composition of the chromian spinel may be a very good indicator of the conditions of crystallization because of the significant range in its composition in basaltic lavas. The range in $\mathrm{Cr} /(\mathrm{Cr}+\mathrm{Al})$ and $\mathrm{Fe}^{2+} /\left(\mathrm{Fe}^{2+}+\mathrm{Mg}\right)$ of magnesiochromite, chromite and magnetite found in lavas that include boninites, mid-oceanic-ridge basalts (MORB) and lavas from Hawaii are shown in Figure 3. The majority of chromian spinel from MORB plot within the area of Figure 3 outlined by the dashed lines. Chromian spinel within a single lava flow, and even within a very small crystal, can show a large range in $\mathrm{Cr} /(\mathrm{Cr}+\mathrm{Al}), \mathrm{Fe}^{2+} /\left(\mathrm{Fe}^{2+}+\mathrm{Mg}\right), \mathrm{Fe}^{3+} /\left(\mathrm{Fe}^{3+}+\mathrm{Al}+\mathrm{Cr}\right)$ and $\mathrm{Ti}$ content. The common trends in chromian spinel and chromite from MORB lavas are shown by the solid lines in Figure 3. The $R-S$ and $T-U$ trends are limited to slowly cooled lavas, where the rim of some chromian spinel crystals may approach titaniferous magnetite (lower right-hand corner of Fig. 3). The variation of $\mathrm{Cr} /$ $(\mathrm{Cr}+\mathrm{Al})$ and $\mathrm{Fe}^{2+} /\left(\mathrm{Fe}^{2+}+\mathrm{Mg}\right)$ in rapidly quenched samples (i.e., trend $P-X$ and $X-Y$, Fig. 3 ) is usually ascribed to changing melt composition owing to crystallization of olivine, plagioclase or chromian spinel before extrusion, or to magma mixing (Allan et al. 1988, 1989). It has also been suggested (Bryan 1972, Sigurdsson \& Schilling 1976, Sigurdsson 1977, Dick \& Bullen 1984) that zoning with respect to $\mathrm{Cr} /(\mathrm{Cr}+\mathrm{Al})$ may be due to changes in pressure during growth of the chromian spinel, the more aluminous chromian spinel being stable at higher pressures.

Here, we document a number of different growthforms of chromian spinel from four MORB glasses and the relationship between these growth forms and the composition of the crystals. The focus is on magmas that have cooled rapidly enough that significant glass is present. Thus the discussion is limited to chromian spinel textures that are considered to be present at the time of extrusion and not those formed during slow cooling of magma. One of the major observations of the present study is that some of the $\mathrm{Cr} /(\mathrm{Cr}+\mathrm{Al})$ compositional variation and the variety of growth forms of chromian spinel may be due to changes in rate of crystal growth and of diffusion-controlled growth, and not to changes in bulk composition of the magma. Chromian spinel may be particularly susceptible to diffusion-controlled growth because of the very large difference in chromium content of chromian spinel and the coexisting melt (Thy 1983). Thus significant changes in the composition of the chromian spinel need not reflect major changes in bulk-melt composition or changes in lithostatic pressure.

\section{SAMPLES AND TECHNIQUES}

The samples of basalt described in the present study have been chosen because they were quenched rapidly enough that glass is the dominant phase. The three samples from Iceland (Mid-P, Mid-2, KBS-1) represent 

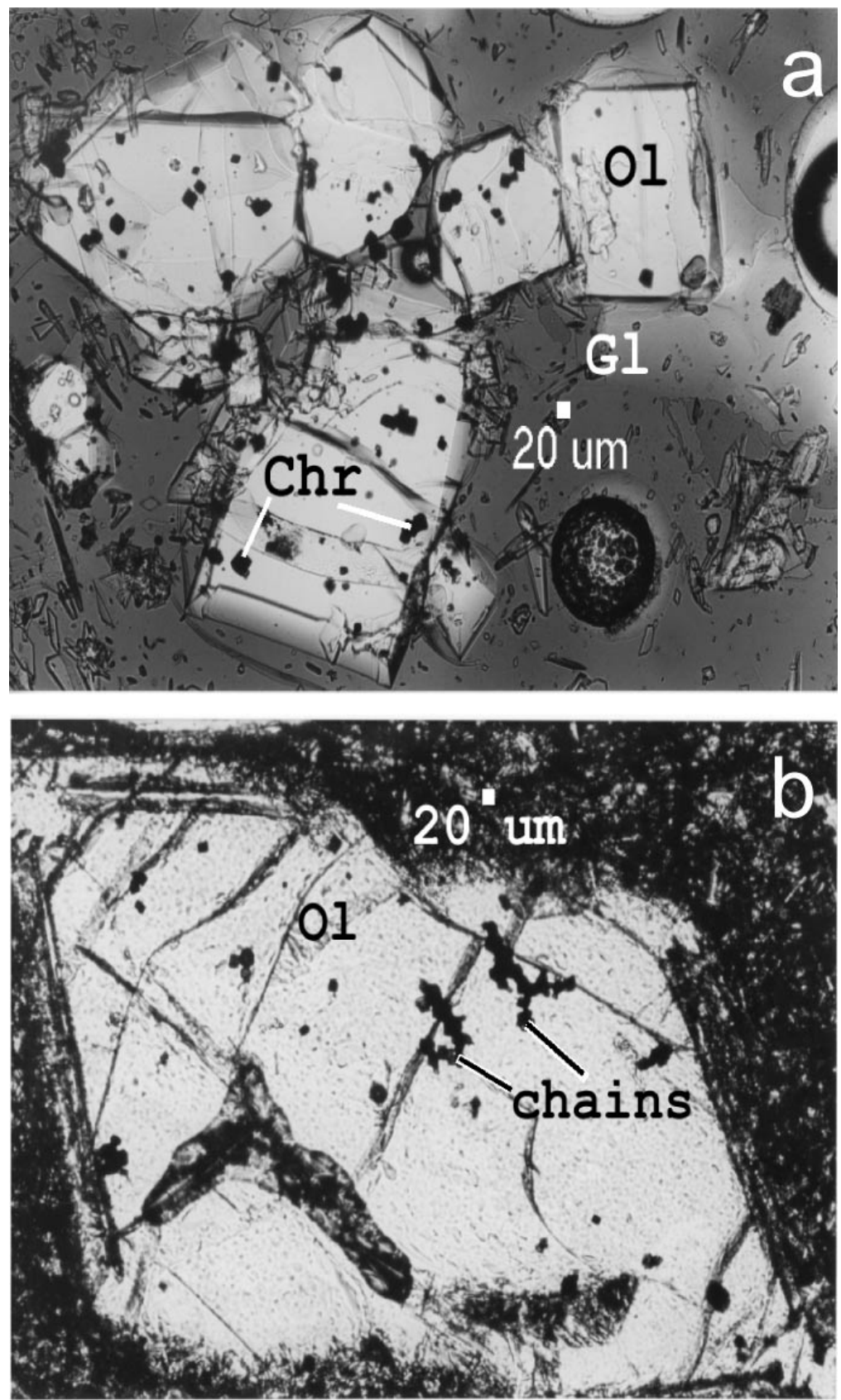

FIG. 1. a. Olivine (Ol) phenocrysts containing small opaque crystals of chromian spinel (Chr) in a vesicular glass (Gl). Sample is a basalt from Iceland (HS-774) provided by H. Sigurdsson. Transmitted light. b. Olivine phenocryst with enclosed opaque grains and chains of chromian spinel in a groundmass of plagioclase and pyroxene microphenocrysts and glass. Sample is a basaltic andesite from Paricutín, Mexico. Transmitted light. The width of the field of view is approximately $1.3 \mathrm{~mm}$. 

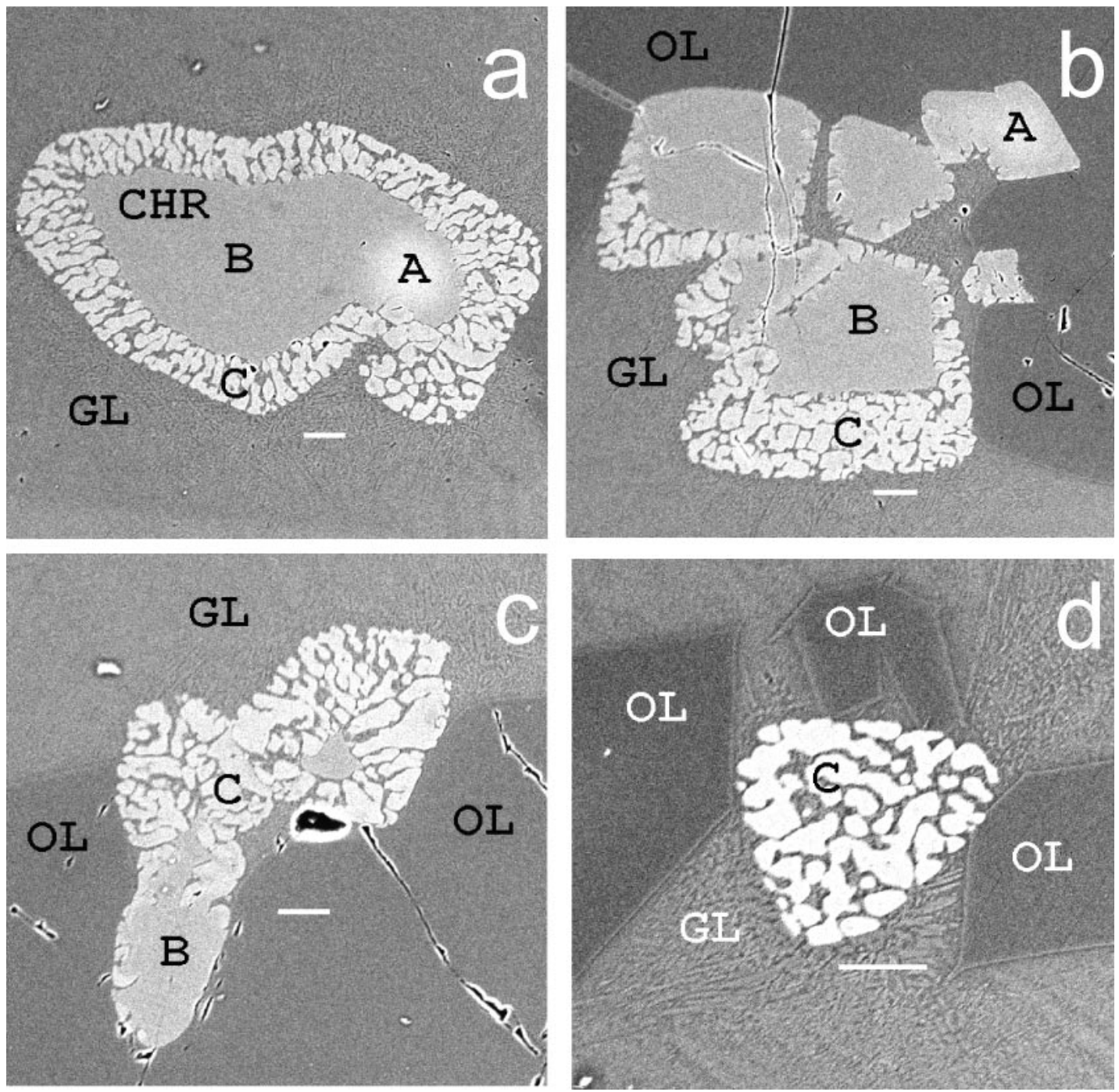

FIG. 2. Back-scattered electron images of crystals of chromian spinel (CHR) with a vermiform rim in basaltic glass (GL) together with olivine (OL) phenocrysts. The letters A, B and C refer to stages of growth as described in the text. Sample ALV520 from the Mid-Atlantic rift zone. The white scale bar represents $20 \mu \mathrm{m}$.

subglacial eruptions in the Western rift-zone of Iceland. In this region of Iceland, the Mid-Atlantic Ridge is offset to the east along a leaky transform fault that runs $75 \mathrm{~km}$ along the Reykjanes Peninsula until it connects to the Western rift-zone of Iceland. At the intersection of the southern termination of the Western rift-zone and the transform structure, there are a series of hyaloclastite ridges of late Quaternary age that make up the Hengill Volcanic Centre. The Hengill suite ranges from picritic basalts to quartz tholeiites. Maelifell (sample KBS-1) is a hyaloclastite pillow ridge on the center of the fis- sure, and Midfell (samples Mid-P, Mid-2) is a hyaloclastite ridge at the northern termination of the marginal fissure, where abundant gabbro xenoliths are dispersed in the pillow breccia. The three Icelandic samples are picrites containing olivine phenocrysts $\left(\mathrm{Fo}_{88-91}\right)$, some clinopyroxene phenocrysts, microphenocrysts of chromian spinel and abundant glass. The petrography, chemical composition and phase composition of the picrites from this region have been described by Hardardottir (1986), Tronnes (1990) and Hansteen (1991). 


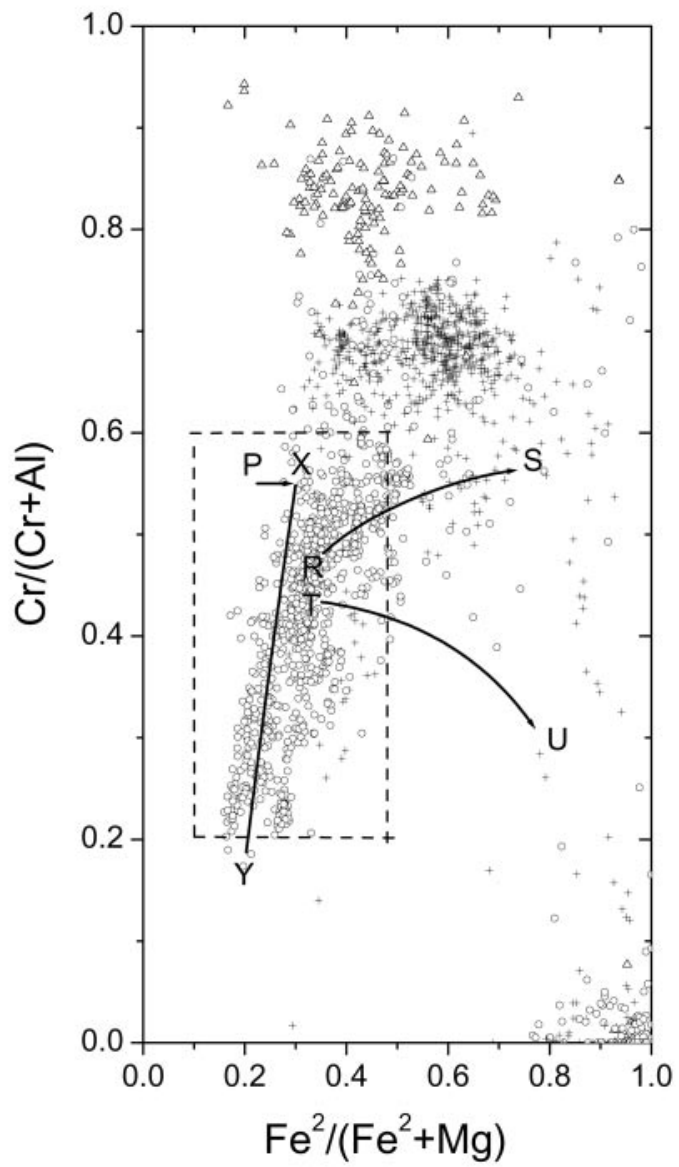

FIG. 3. $\mathrm{Cr} /(\mathrm{Cr}+\mathrm{Al})$ versus $\mathrm{Fe}^{2+} /\left(\mathrm{Fe}^{2+}+\mathrm{Mg}\right)$ of magnesiochromite, chromite and magnetite from boninites, Hawaiian lavas and MORB lavas. $\mathrm{N}=$ no. of samples. Analytical data from the spinel database described by Roeder (1994). The solid curves represent common trends of chromian spinel found in MORB lavas. See text for details. Symbols: $\Delta$ chromian spinel from boninite $(\mathrm{N}=157),+$ chromian spinel from Hawaiian basalt $(\mathrm{N}=704)$, 。 chromian spinel from mid-ocean-ridge basalt $(\mathrm{N}=1010)$.

The F2 samples (F2-1, F2-2) are dredged samples of a pillow margin quenched by seawater from just west of the East Pacific Rise. These samples were described in detail by Allan et al. $(1988,1989)$ and were found to contain about $15 \%$ phenocrysts of olivine and plagioclase and less than $0.1 \%$ by volume of chromian spinel microphenocrysts. The olivine (Fo87-90) is generally skeletal, and some rims are reversely zoned by $1-2 \%$ Fo. The plagioclase phenocrysts may be very large, skeletal and filled with glass inclusions, which suggests relatively rapid growth of the phenocrysts. Careful broad-beam electron-microprobe analysis of the matrix glass in F2-1 and F2-2 led Allan et al. (1988) to sug- gest that the majority of the $\mathrm{Cr}$ measured for the bulk samples (440-460 ppm Cr) is in the glass.

The electron-microprobe analyses and the back-scattered electron (BSE) images for the present study were collected using an ARL SEMQ electron microprobe fitted with an energy-dispersion detector and a Robinson BSE detector. The microprobe analyses of the glasses and chromian spinel were made by energy-dispersion spectrometry (EDS) at $15 \mathrm{kV}$, except for the concentration of chromium in the glass, which was established by wavelength-dispersion (WDS) analysis at $25 \mathrm{kV}$, as described by Roeder \& Reynolds (1991). The EDS electron-microprobe analysis of glass was of a scanned area $(20 \times 20 \mu \mathrm{m})$, whereas the chromian spinel was analyzed with a focused beam. Standards included chromian spinel and olivine from the Smithsonian Institution, glass from the U.S. National Bureau of Standards, and basaltic glasses from Gaetani et al. (1995). The proportion of $\mathrm{Fe}^{2+}$ and $\mathrm{Fe}^{3+}$ in chromian spinel was calculated assuming stoichiometry.

\section{Growth Forms AND Composition of Chromian SPinel}

The dominant crystal forms of chromian spinel in all four samples are octahedra and rare chains of attached octahedra. The small size of most crystals and the translucent to opaque nature of the chromian spinel make it very difficult to visualize the shape of the crystals, and thus the combination of a view in transmitted light and a BSE image is useful. The grain of chromian spinel in Figure 4 has a core and vermiform rim very similar to that shown in Figure 2, except that in this case, the chromian spinel has a hole in the center. This morphology suggests that this is a hopper crystal. Figure 5 shows examples of chains of chromian spinel crystals that are oriented with respect to each other. The transmitted-light view (Fig. 5a) gives the impression of a chain of three simple octahedra, whereas the BSE image (Fig. 5b) shows the rim of the crystals to be much more complex and zoned. The rim and the hole in the center of the chromian spinel are similar to those of the crystal shown in Figure 4. An example of a chromian spinel chain attached to a small crystal of olivine is shown in Figures $5 \mathrm{c}-\mathrm{d}$. The crystals in this chain have skeletal extensions that are zoned, and the crystals are considerable larger than the average crystals of chains in volcanic rocks, for example those in Figures 1a and $1 \mathrm{~b}$. Note that the scale bar in all figures represents 20 $\mu \mathrm{m}$, which is the usual size of chromian spinel in volcanic rocks. There is a great variety of crystal shapes within individual samples and even within the same crystal grouping. Thus within the individual crystals shown in Figures $5 \mathrm{c}$ and $5 \mathrm{~d}$, the texture can be described as euhedral to anhedral, containing both rational planar crystal faces and irregular shapes that give part of the crystal a wormy or vermiform appearance. Many of the chromian spinel crystals in the four basalts are skeletal 

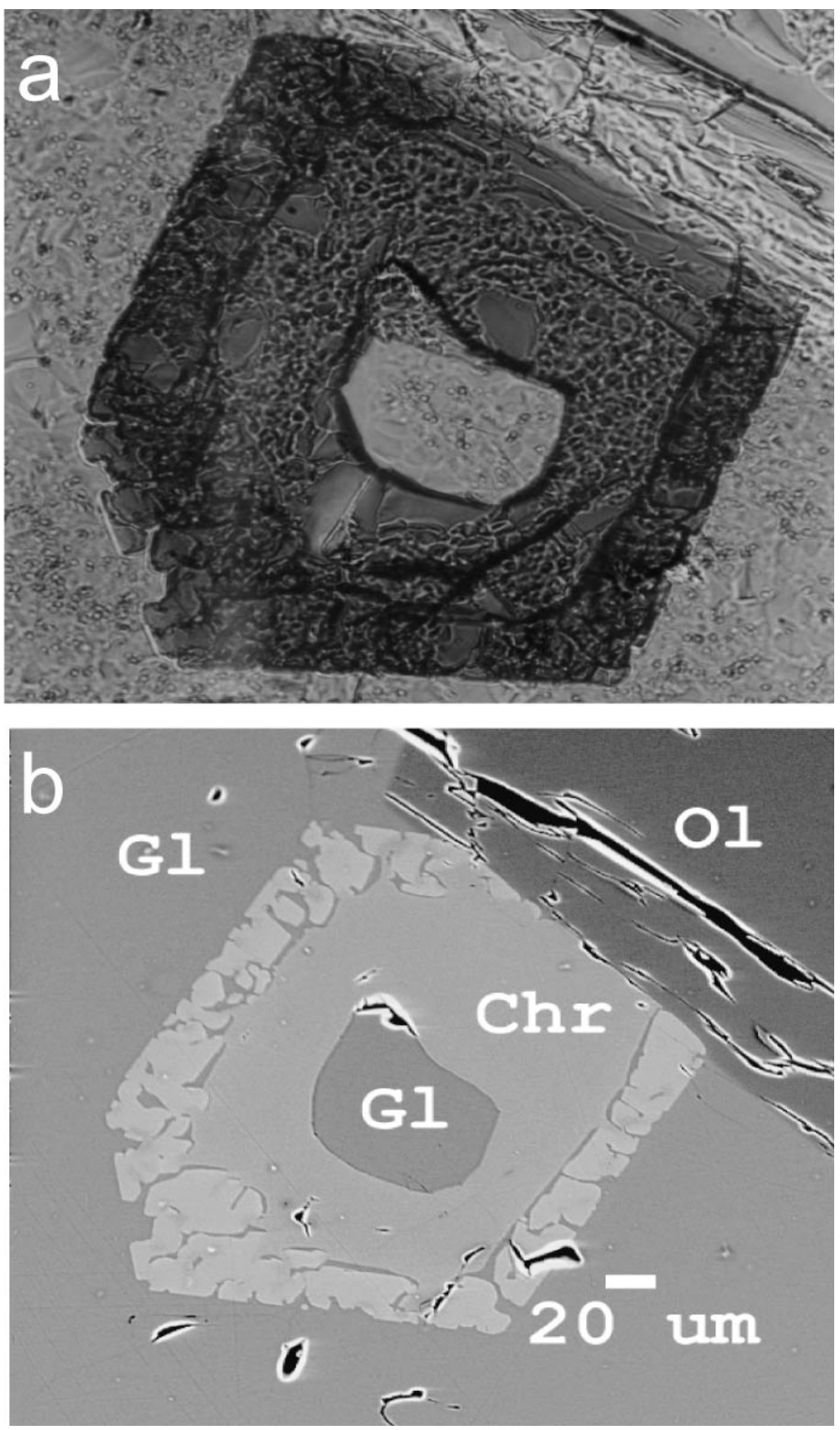

FIG. 4. a. Crystal of chromian spinel with a vermiform rim attached to an olivine phenocryst in a basaltic glass. Transmitted light. b. Back-scattered electron (BSE) image of above. Sample F2-2 from East Pacific Rise (Allan et al. 1988). The white bar represents $20 \mu \mathrm{m}$. 

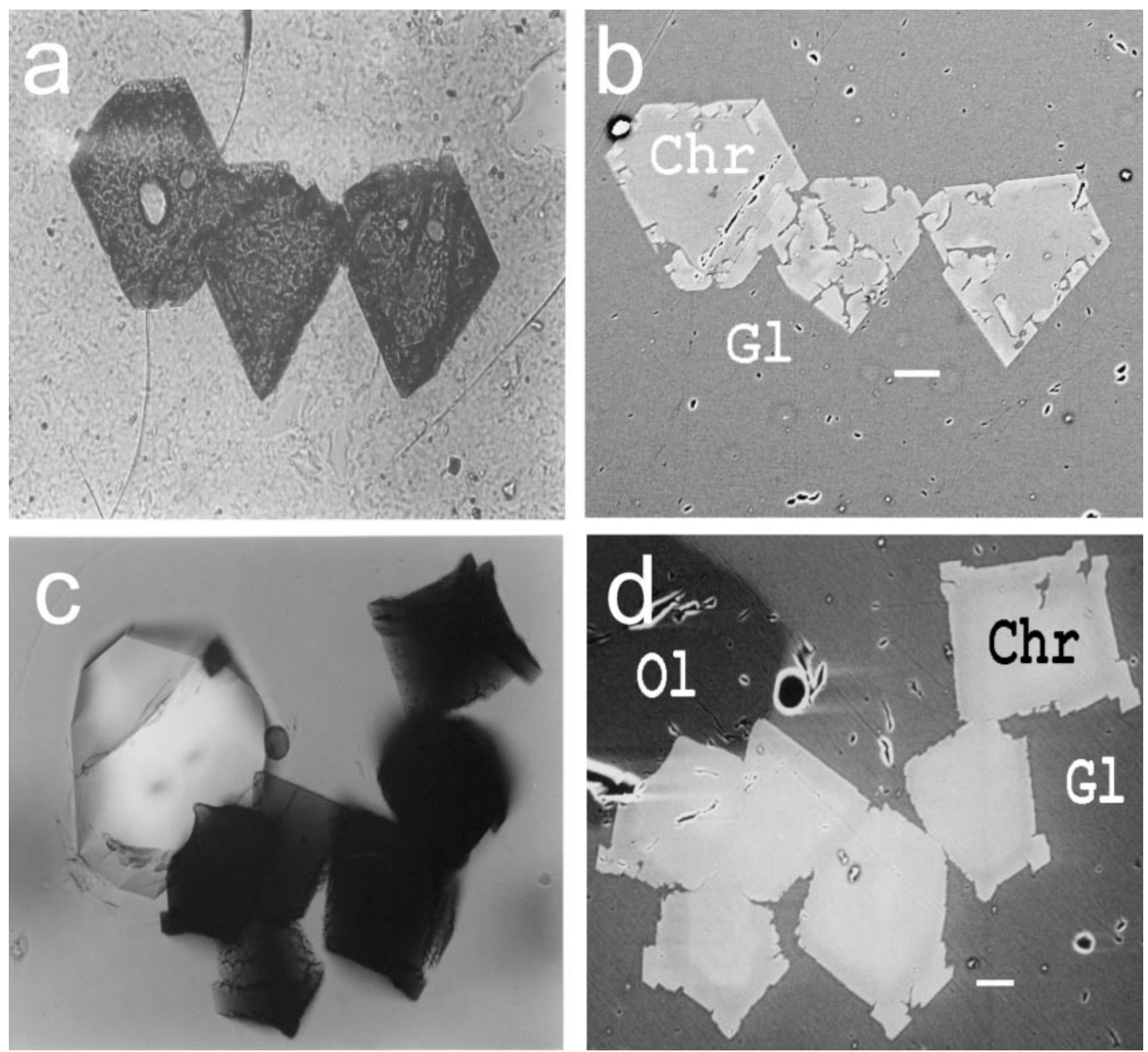

FIG. 5. a. Chain of three octahedra of chromian spinel in basaltic glass. Sample F2-1 from East Pacific Rise (Allan et al. 1988). Transmitted light. b. BSE image of above. c. Olivine crystal with an attached chain of chromian spinel in glass. Sample Mid2 from Iceland. Transmitted light. d. BSE image of above. The white bar represents $20 \mu \mathrm{m}$.

and contain areas of included glass that are considered to be contiguous with the matrix glass in three dimensions. Some of these crystals are hopper crystals, in which the growth rate of corners and edges was faster than that of the crystal faces, thus accounting for the apparent hole in the crystals as seen in two dimensions. A sample from a recent Hawaiian eruption (Fig. 6) has been included because it shows the development of chain texture in chromite and how the continued growth of the chain (left of Fig. 6) could lead to areas of glass surrounded by chromite. There is little doubt after examining hundreds of chromian spinel crystals that hopper crystals, chains and planar and vermiform crystal surfaces are commonly juxtaposed and that they formed during the same crystallization event.

The majority of the chromian spinel crystals in the four samples that are in contact with glass are zoned with respect to $\mathrm{Cr} /(\mathrm{Cr}+\mathrm{Al})$ and $\mathrm{Fe}^{2+} /\left(\mathrm{Fe}^{2+}+\mathrm{Mg}\right)$, but display only a small variation (not shown) in $\mathrm{Fe}^{3+} /\left(\mathrm{Fe}^{3+}\right.$ $+\mathrm{Al}+\mathrm{Cr}$ ) or Ti. The contrast in brightness of the BSE image of the crystals depends mainly upon differences in average atomic number of the elements $\mathrm{Mg}, \mathrm{Al}, \mathrm{Cr}$ and Fe. The BSE images of these crystals reflect subtle changes in composition which involve the coupled substitution of the light elements of $\mathrm{Mg}$ and $\mathrm{Al}$ (darker BSE image) for the heavier elements $\mathrm{Fe}$ and $\mathrm{Cr}$ (brighter BSE 


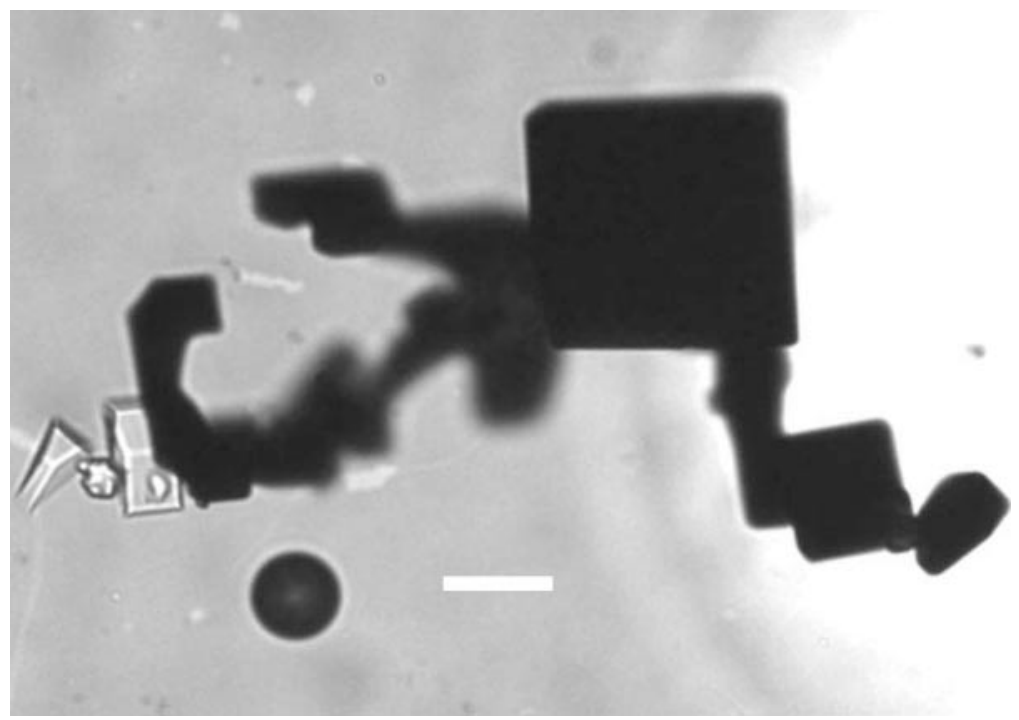

FIG. 6. Chain of chromian spinel octahedra in glass sample (KE53-1740) collected in 1996 from lava-tube skylight at Kilauea, Hawaii (courtesy of Carl Thornber). Note the vesicle to the right of the chain and the small crystals of olivine on the left side of the chain. The white bar represents $20 \mu \mathrm{m}$. Transmitted light.

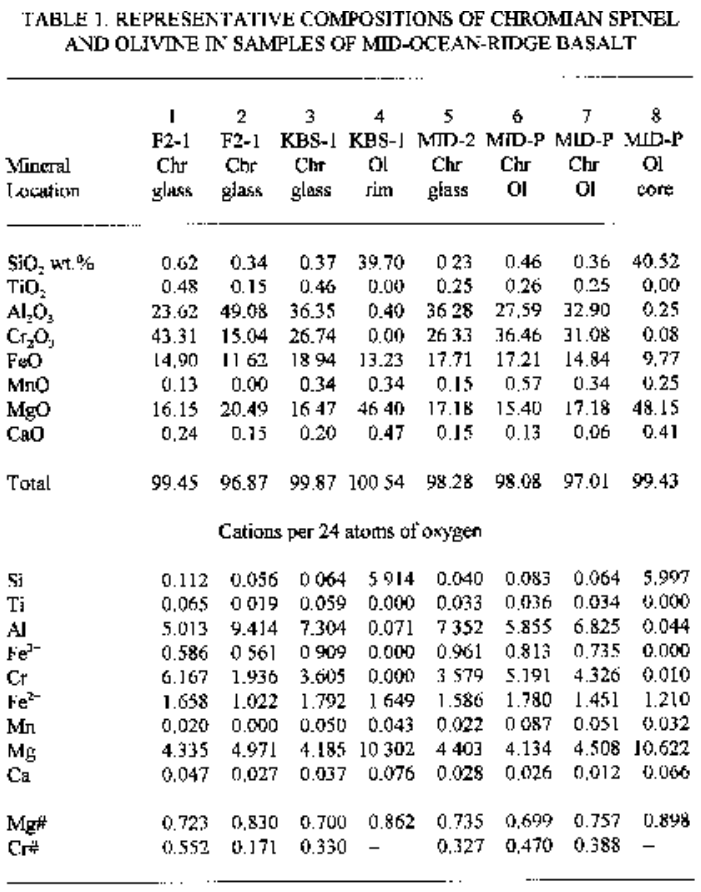

$\mathrm{Yg}+\mathrm{Mg}\left(\mathrm{Mg}+\mathrm{Fe}^{2+}\right) ; \mathrm{Cr}=\mathrm{Cr}(\mathrm{Cr}-\mathrm{A})$
TABI.F. 2. FI.FCTEON-PICROPROBF DATA ON GH.ASS COMPOSCTION TN SATPLES OF MTD-OKEAN-RTDGE EASALT

\begin{tabular}{|c|c|c|c|c|c|c|c|c|c|}
\hline $\begin{array}{l}\text { Wo. } \\
\text { Sample }\end{array}$ & $\begin{array}{c}1 \\
\text { MLP-P }\end{array}$ & $\frac{2}{4 \mathrm{~L}^{2}-2}$ & $\frac{3}{\mathrm{KBS}^{-1}}$ & $\begin{array}{c}4 \\
F 2-1\end{array}$ & & $\frac{1}{\text { MIIINP }}$ & $\stackrel{2}{y-2}$ & $\begin{array}{c}3 \\
\text { KES-1 }\end{array}$ & $\begin{array}{c}4 \\
12-1\end{array}$ \\
\hline $\mathrm{SiO}_{2}$ wh $\%$ & 47.68 & 47.46 & 48.31 & 48.35 & $\mathrm{Si}^{4}$ & 7.067 & 7.057 & $\quad 7.120$ & 7.058 \\
\hline $\mathrm{T}_{1}^{1} \mathrm{O}_{2}$ & 0.73 & 0.74 & 0,98 & 9.79 & $\Gamma \mathrm{i}$ & 0082 & 0.082 & 0.108 & 0.087 \\
\hline $\mathrm{Al}_{2} \mathrm{O}_{1}$ & 15.29 & 15.03 & 14.75 & $16.60^{\circ}$ & Al & 2670 & 2634 & 2561 & 2.867 \\
\hline $\mathrm{Cr}_{2} \mathrm{O}_{3}$ & 0.055 & 550.0546 & 30.0571 & 10.0423 & $\mathrm{or}$ & 0007 & 0.007 & - 0.607 & 0005 \\
\hline$F \& 0^{\circ}$ & 9.08 & 9,04 & 9,53 & 8.01 & $\mathrm{Fe}$ & 1.125 & 1.124 & 1.175 & 0.977 \\
\hline $\mathrm{MaO}$ & 0.15 & 0.14 & 0.16 & 0.18 & Mn & 10019 & 0.017 & - 0020 & 0.023 \\
\hline $\mathrm{MyO}$ & 9.17 & 9.67 & 9,02 & 9.66 & $\mathrm{M}_{\mathrm{B}}$ & 2.024 & 2.132 & $\quad 1.581$ & 2.10 \\
\hline $\mathrm{CaO}$ & 14.66 & 14.39 & 14.52 & 12.82 & $\mathrm{CA}$ & 2.328 & 2.293 & 2.292 & 2.005 \\
\hline$N_{a_{1}} \mathrm{O}$ & 1.33 & 1.38 & 1.57 & 2.13 & $\mathrm{Na}$ & 0.263 & 0306 & 0447 & 0.601 \\
\hline $\mathrm{K}_{2} \mathrm{O}$ & 0.05 & 0.02 & 0,05 & 0.01 & $\mathbf{K}$ & 0.0609 & $0 . \mathrm{CH}$ & $0<109$ & 0.002 \\
\hline \multicolumn{6}{|c|}{$\mathrm{Mg}\left(\mathrm{Mg}+\mathrm{Fe}^{2+}\right)$} & 0.543 & $065 \overline{3}$ & 0.628 & 0.685 \\
\hline Total & 98.17 & 97.83 & 98,9 & 94,62 & $M$ & 6 & 6 & 6 & 7 \\
\hline
\end{tabular}

* Cations per 24 atoms of oxyent. Proportion of $\mathrm{C}_{2} \mathrm{O}_{3}$ established by wayciongthdisptsion sptctiomelry.

image). The complex variation in the crystal form and chemical zoning of the chromian spinel in the four basalts are shown in Figures 7-11. The scale of $\mathrm{Cr} /(\mathrm{Cr}$ $+\mathrm{Al})$ versus $\mathrm{Fe}^{2+} /\left(\mathrm{Fe}^{2+}+\mathrm{Mg}\right)$ in these figures is indicated by the dashed rectangle in Figure 3. Selected compositions of chromian spinel and olivine are given in Table 1, and the composition of the glass in the four samples is given in Table 2 . The $\mathrm{Cr} /(\mathrm{Cr}+\mathrm{Al})$ versus 


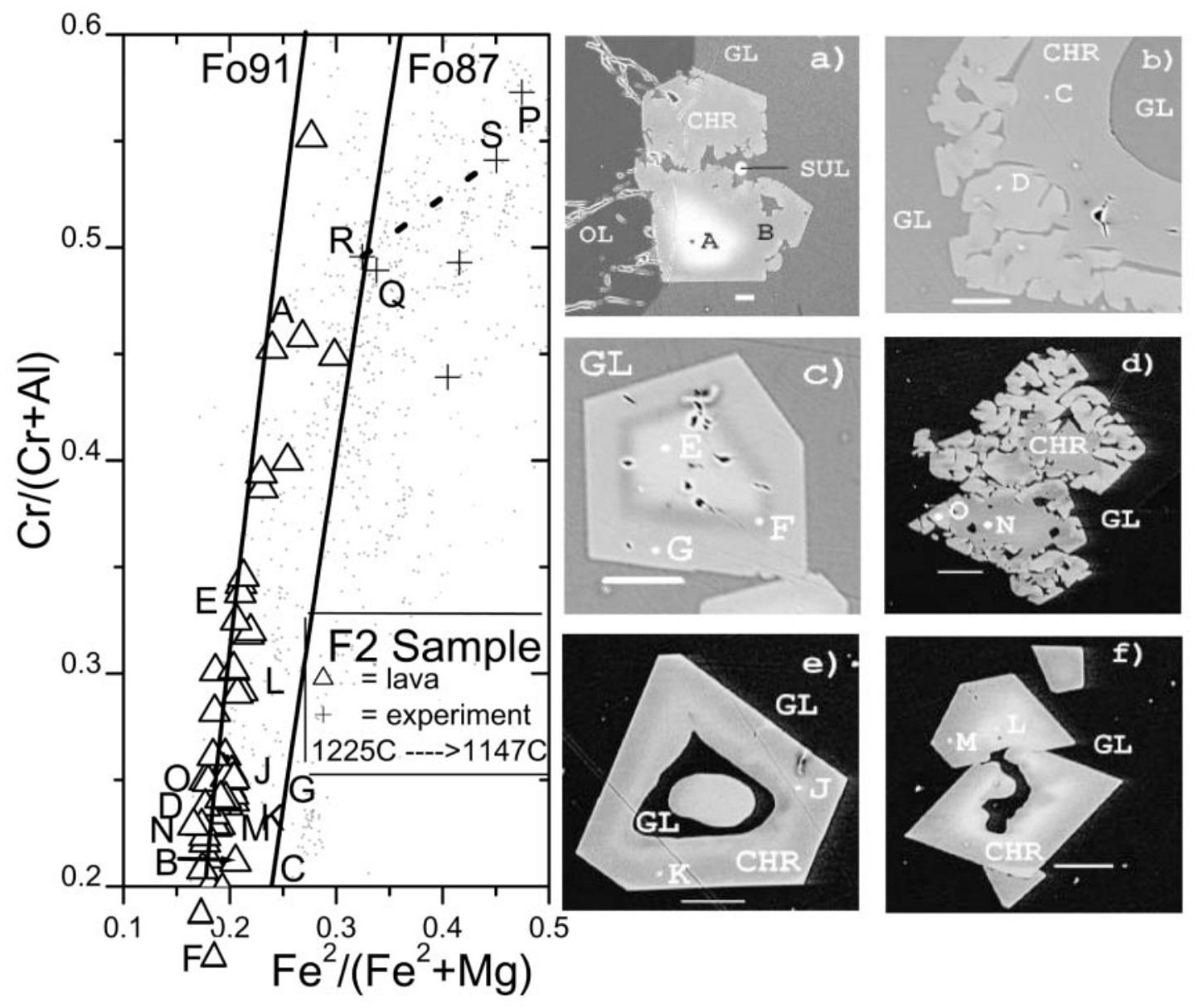

FIG. 7. $\mathrm{Cr} /(\mathrm{Cr}+\mathrm{Al})$ versus $\mathrm{Fe}^{2+} /\left(\mathrm{Fe}^{2+}+\mathrm{Mg}\right)$ for chromian spinel in samples $\mathrm{F} 2-1$ and $\mathrm{F} 2-2$. Open triangles represent chromian spinel in lava, crosses (+), chromian spinel in experimental runs, and small symbols are the same as in Figure 3. Photos a-f are BSE images of chromian spinel; the letters designate the location where the analyses were made. Figure 7a displays an immiscible sulfide (SUL) bleb. The two solid curves were calculated assuming equilibrium (Poustovetov 2000) between olivine ( $\mathrm{Fo}_{91}$ and $\left.\mathrm{Fo}_{87}\right)$ and chromian spinel at $1213^{\circ} \mathrm{C}$ (see text for details). The dotted line connects the core (R) and rim (S) compositions of a chromian spinel in the experimental run. The white bar represents $20 \mu \mathrm{m}$.

$\mathrm{Fe}^{2+} /\left(\mathrm{Fe}^{2+}+\mathrm{Mg}\right)$ values of chromian spinel for each basalt are shown on the graphs by the large open triangles and circles. The very small circles on these graphs represent the compositions of chromian spinel from the MORB-type basalts in the spinel database (Fig. 3; Roeder 1994) and are shown for comparison. Each of the graphs is accompanied by a number of BSE images; these demonstrate the diversity of growth forms in each of the samples. The upper-case letters on the BSE images show the position of an electron-microprobe analysis, which corresponds with the labeled symbol on the graph. The two solid curved lines on each graph were calculated using the equations described by Poustovetov (2000) assuming an equilibrium between olivine and chromian spinel at a constant temperature. These lines are the equivalent of the "equipotential" lines introduced by Irvine (1965). The olivine composition used for the calculation is shown beside each line; the range in olivine composition used for each sample covers the majority of olivine measured for that particular sample. The average $\mathrm{Ti}$ and $\mathrm{Fe}^{3+}$ in the spinel for each sample were used for the calculation. The temperature used for each "equipotential" line was calculated from the glass composition using the method of Beattie (1993) and is given in each figure caption.

\section{Basalts $F 2-1$ and $F 2-2$}

The MORB samples F2-1 and F2-2 (Fig. 7) are from the flank of the East Pacific Rise and have the highest 

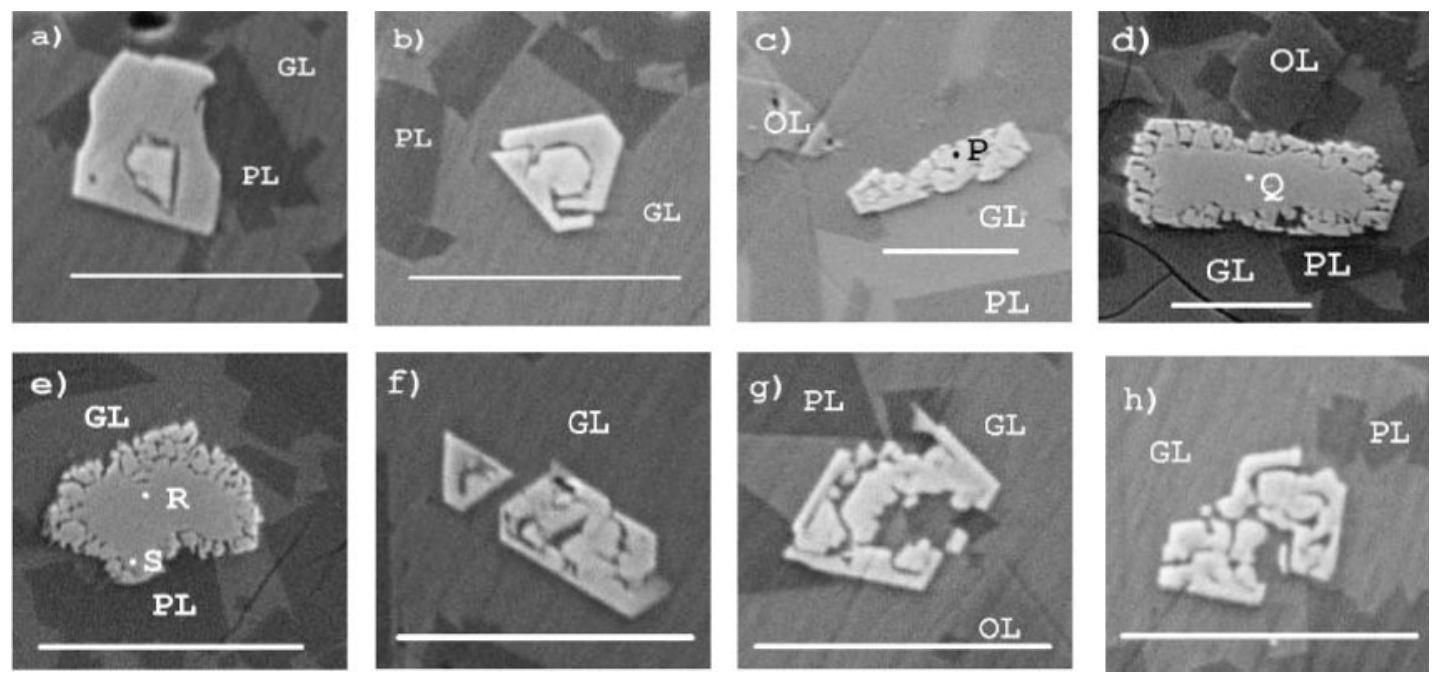

FIG. 8. BSE images of chromian spinel in experimental run for sample F2-1 cooled from 1225 to $1147^{\circ} \mathrm{C}$ over eight hours. Other phases are glass (GL), olivine (OL) and plagioclase (PL). Letters refer to the locations where the analyses (crosses Fig. 7) were made. The white bar represents $20 \mu \mathrm{m}$.

amount of $\mathrm{Mg}$ in the glass (9.66 wt.\% $\mathrm{MgO}$ ) of the four samples, and the chromian spinel from F2-1 and F2-2 are lowest in $\mathrm{Fe}^{2+} /\left(\mathrm{Fe}^{2+}+\mathrm{Mg}\right)$. Note that the chromian spinel in sample $\mathrm{F} 2$ has $\mathrm{Fe}^{2+} /\left(\mathrm{Fe}^{2+}+\mathrm{Mg}\right)$ values comparable to the lowest $\mathrm{Fe}^{2+} /\left(\mathrm{Fe}^{2+}+\mathrm{Mg}\right)$ of the whole "MORB spinel" database (tiny circles). The skeletal chromian spinel attached to olivine shown in the BSE image of Figure $7 \mathrm{a}$ is zoned from a $\mathrm{Cr} /(\mathrm{Cr}+\mathrm{Al})$ of 0.46 in the core (A) to 0.21 at the rim (B), which is the maximum range of $\mathrm{Cr} /(\mathrm{Cr}+\mathrm{Al})$ measured for a single crystal of chromian spinel in all four basalts. This crystal is also interesting because the crystallization of the chromian spinel may have been responsible for the nucleation of the bleb of an immiscible sulfide melt shown in Figure 7a. The chromian spinel shown in Figure $7 \mathrm{~b}$ is part of the rim of the chromian spinel shown in Figure 4. The difference in composition between the core (C in Fig. 7b) and the vermiform rim (D) is distinct, but quite small. Note in Figure $7 \mathrm{~b}$ and $7 \mathrm{~d}$ the development of planar outer edges of the vermiform chromian spinel near the glass. There is a natural tendency to assume that concentrically zoned crystals start to form at the core and that crystallization proceeds toward the rim. The chromian spinel in Figure 7c may indeed have crystallized from the center outward, but crystals such as in Figures $7 \mathrm{e}$ and $7 \mathrm{f}$ appear to be hopper shaped. In this case, crystallization may well have started in the higher $\mathrm{Cr} /(\mathrm{Cr}+\mathrm{Al})$ zone $(\mathrm{J})$ and proceeded both inward and outward, leaving a crystal that appears in two dimensions to have a hollow center. Thus one can imagine that a concentrically zoned crystal, as seen in two dimensions, may have been a hopper crystal that became filled in and that the center, the so-called core, formed later than the rim.

\section{Experimental run on $\mathrm{F} 2-1$}

Roeder \& Reynolds (1991) conducted a number of experiments on sample F2-1 at different temperatures and using various cooling regimes. The samples from these experiments were re-examined as part of the present study, and one experiment was found that has growth habits of chromian spinel very similar to those in the F-2 lavas. Examples from this experiment are shown in Figure $8(a-h)$. Note that the crystals from the experiment are an order of magnitude smaller than those in the lava sample. The experiment was held at $1225^{\circ} \mathrm{C}$ for 67 hours and then cooled slowly over eight hours to $1147^{\circ} \mathrm{C}$ [at an $f\left(\mathrm{O}_{2}\right)$ extrapolated to be the QFM buffer] and then the sample was quenched. The results of this experiment were not published by Roeder \& Reynolds (1991) because it was a dynamic (slowly cooled) experiment.

The morphology of the grains of chromian spinel in the experimental run are complex and varied, but comparable to that of crystals in the MORB samples. The solid core and vermiform rim in Figures 8d and 8e are very similar to those of the chromian spinel shown in Figure 2 and Figure 7b. The complex combination of planar faces and the openness of the interior of the grain with rounded vermiform shapes are similar in the run product (Fig. 8g) and in Figure 7a. The similarity in form between the chromian spinel of Figures 8b, f, and $\mathrm{g}$ and the chromian spinel from the podiform chromitite 


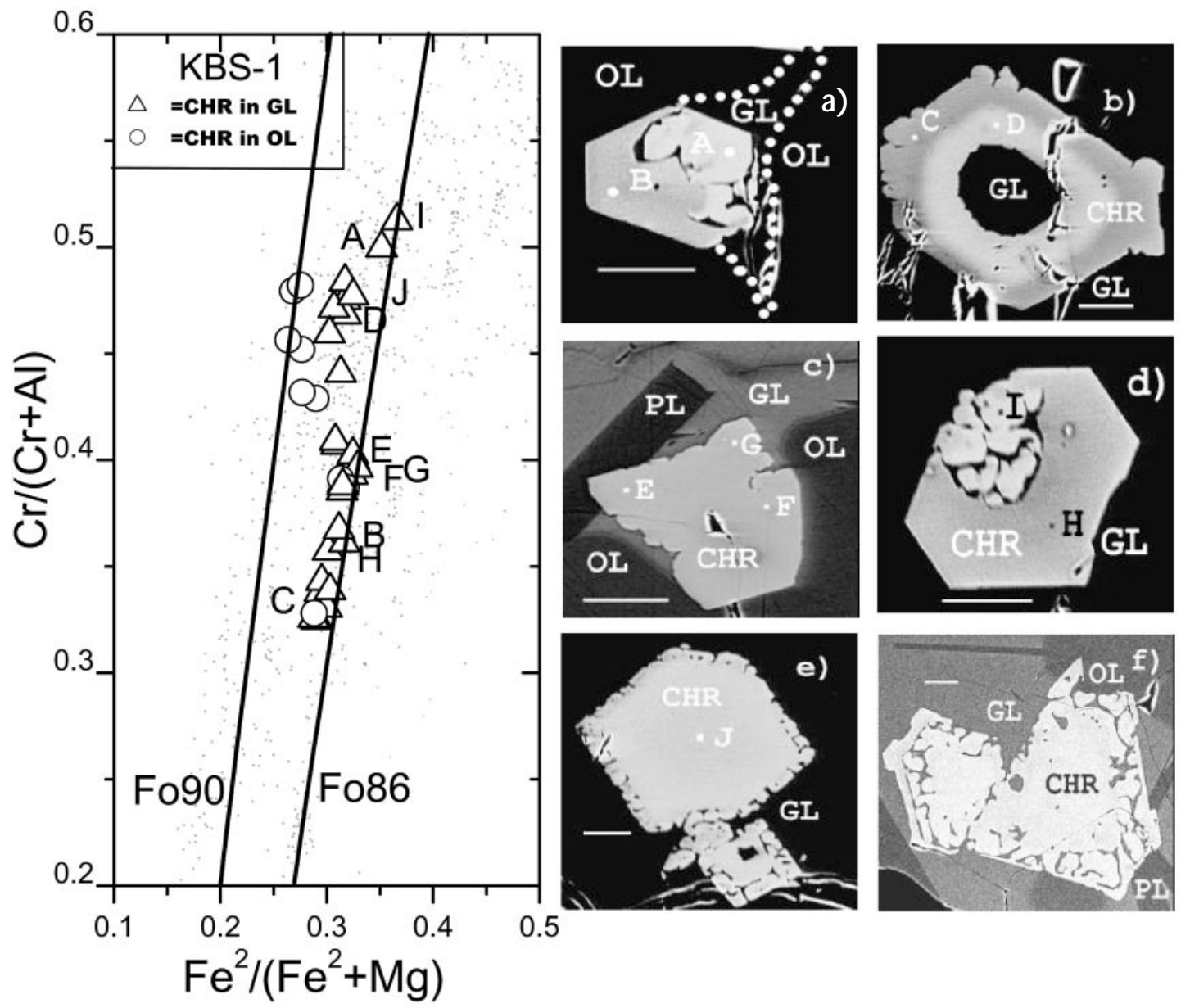

FIG. 9. $\mathrm{Cr} /(\mathrm{Cr}+\mathrm{Al})$ versus $\mathrm{Fe}^{2+} /\left(\mathrm{Fe}^{2+}+\mathrm{Mg}\right)$ for chromian spinel in sample $\mathrm{KBS}-1$ from Iceland. Photos a-f are BSE images of chromian spinel. Open circles represent chromian spinel completely enclosed in olivine, and triangles represent chromian spinel beside glass. Dotted line in photo a has been added to enhance the olivine-glass boundary. The two solid curves were calculated assuming equilibrium (Poustovetov 2000) between olivine ( $\mathrm{Fo}_{90}$ and $\mathrm{Fo}_{86}$ ) and chromian spinel at $1200^{\circ} \mathrm{C}(\mathrm{see} \mathrm{text}$ for details).

shown in Figure 5a of Christiansen \& Olesen (1990) is striking, although they differ in size by a factor of about 1000. It was difficult to document the composition of the vermiform part of the chromian spinel in the experimental run because of the very small size of the crystals. However, the vermiform parts of the chromian spinel in the run (e.g., Fig. 8e) have a significantly higher $\mathrm{Fe}^{2+} /\left(\mathrm{Fe}^{2+}+\mathrm{Mg}\right)$ than the core, as shown by the trend $R-S$ in Figure 7.

\section{Basalt KBS-1}

The sample KBS- 1 has the lowest $\mathrm{Mg}$ content in the glass $(9.02 \mathrm{wt} \% \mathrm{MgO})$ of the four basalts, and the chromian spinel in KBS-1 (Fig. 9) has a higher $\mathrm{Fe}^{2+} /$ $\left(\mathrm{Fe}^{2+}+\mathrm{Mg}\right)$ than the chromian spinel in the other three samples. The chromian spinel crystals tend to be smaller and more compact, and the range in $\mathrm{Cr} /(\mathrm{Cr}+\mathrm{Al})$ is lower than in the other samples. Some of the crystals in KBS-1 appear in transmitted light to be simple compact octahedra, but the BSE images (Figs. 9a, d) show that part of each octahedron has a vermiform texture with a higher $\mathrm{Cr} /(\mathrm{Cr}+\mathrm{Al})$ value. The very local change in habit and $\mathrm{Cr} /(\mathrm{Cr}+\mathrm{Al})$ of these two crystals is similar to that of the chromian spinel in the experimental run (Figs. 8a, b). The chromian spinel in Figure 9c seems to be euhedral where enclosed in olivine and plagioclase, but vermiform and smaller where exposed to the glass. 


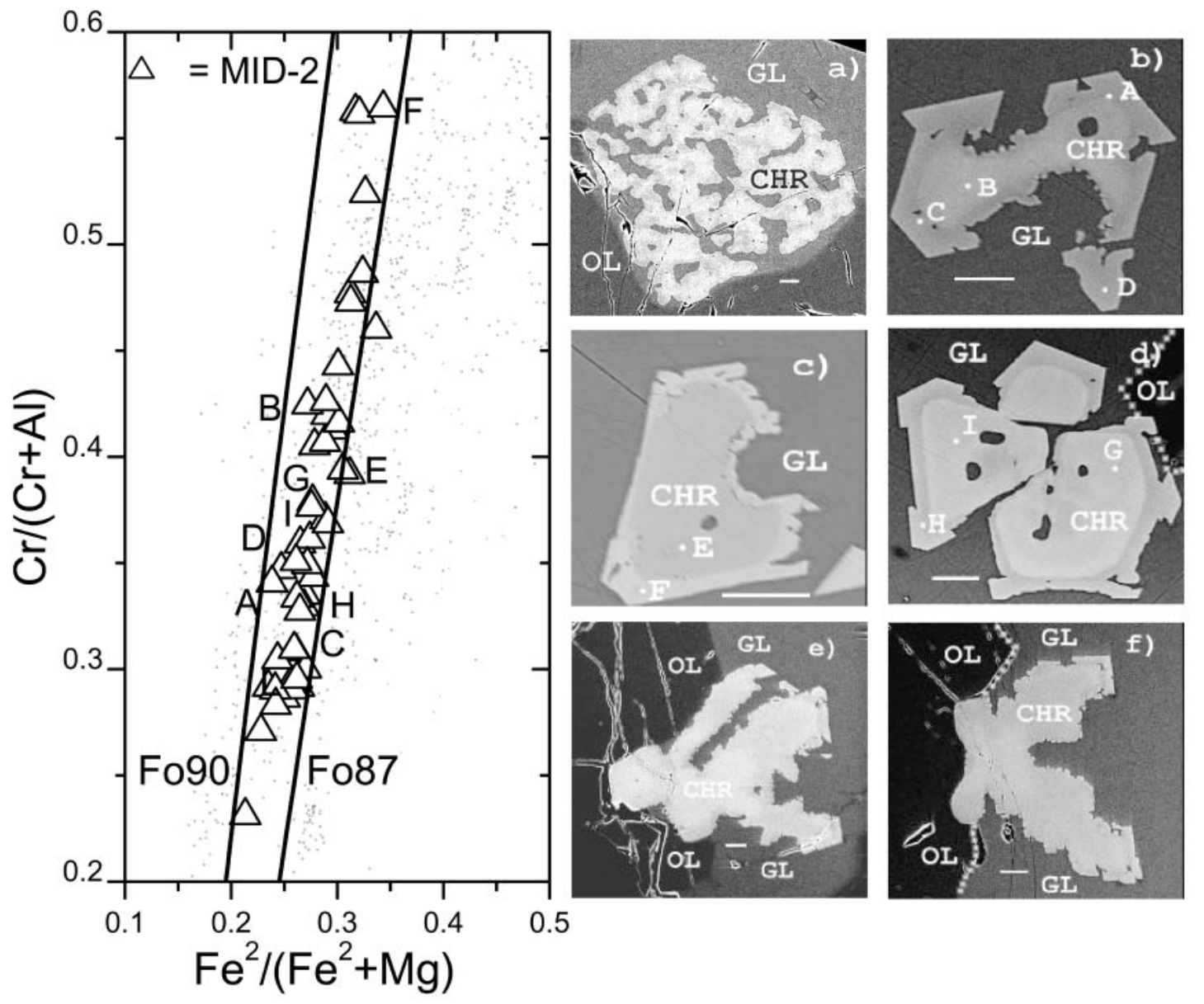

FIG. 10. $\mathrm{Cr} /(\mathrm{Cr}+\mathrm{Al})$ versus $\mathrm{Fe}^{2+} /\left(\mathrm{Fe}^{2+}+\mathrm{Mg}\right)$ for chromian spinel in sample Mid-2 from Iceland. Photos a-f are BSE images of chromian spinel. Dotted line in photos $\mathrm{d}$ and $\mathrm{f}$ have been added to enhance the olivine-glass boundary. Symbols as in Figure 7. The two solid curves were calculated assuming equilibrium (Poustovetov 2000) between olivine ( $\mathrm{FO}_{90}$ and $\left.\mathrm{Fo}_{87}\right)$ and chromian spinel at $1215^{\circ} \mathrm{C}$ (see text for details).

The chromian spinel completely enclosed in olivine (large circles) commonly has a lower $\mathrm{Fe}^{2+} /\left(\mathrm{Fe}^{2+}+\mathrm{Mg}\right)$ than the chromian spinel in glass, and this is consistent with olivine cores having a higher forsterite $\left(\mathrm{Fo}_{90-89}\right)$ content than the olivine rims $\left(\mathrm{Fo}_{85}\right)$.

\section{Basalt Mid-2}

The chromian spinel crystals in the Mid-2 sample (Fig. 10) are typically skeletal and combine planar faces with a vermiform texture. The planar faces commonly are oriented toward the large open areas of glass, whereas the vermiform texture is commonly found in re-entrants (Figs. 10b, d-f). Careful examination of the so-called irregular interface with the glass in
Figures $10 \mathrm{e}-\mathrm{f}$ indicates a parallelism of planes throughout, and thus both of these irregular chromian spinel grains are single crystals. These two crystals seem to have nucleated at the olivine-glass interface and grown outward toward the glass with contemporaneous growth of olivine and chromian spinel. The contrast in the BSE images has been set to accentuate the chromian spinel zoning; as a result, the boundary between olivine and glass is not always easily seen. Thus a dotted line has been added in some cases to accentuate the olivine-glass boundary (i.e., Figs. 10d, f). Note that the measured compositions of chromian spinel appear to form an almost linear array parallel to, and between, the so-called "isopotential" curves. 


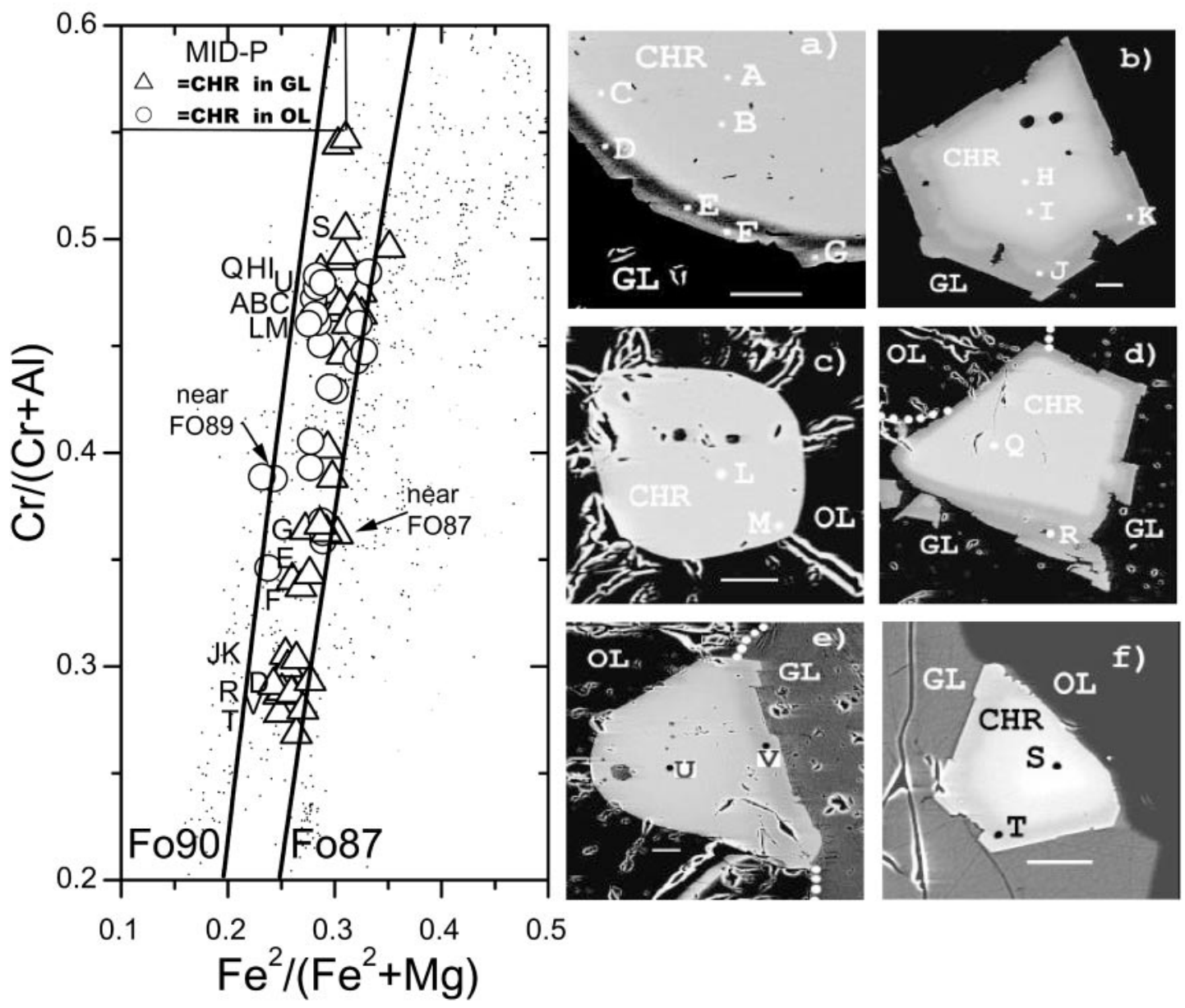

FIG. 11. $\mathrm{Cr} /(\mathrm{Cr}+\mathrm{Al})$ versus $\mathrm{Fe}^{2+} /\left(\mathrm{Fe}^{2+}+\mathrm{Mg}\right)$ for chromian spinel in sample Mid-P from Iceland. Open triangles represent chromian spinel in contact with glass, and open squares represent chromian spinel enclosed in olivine. Photos a-f are BSE images of chromian spinel. Symbols as in Figure 7. The two solid curves were calculated assuming equilibrium (Poustovetov 2000 ) between olivine ( $\mathrm{Fo}_{90}$ and $\mathrm{Fo}_{87}$ ) and chromian spinel at $1202^{\circ} \mathrm{C}$ (see text for details).

\section{Basalt Mid-P}

Figure 11a shows a small portion of a relatively large $(700 \mu \mathrm{m})$ crystal of chromian spinel that is uniform in composition (A, B and C) except for a narrow rim that is strongly zoned (D-G). The other grains of chromian spinel in this sample vary from small octahedra to somewhat skeletal crystals. The round chromian spinel in Figure $11 \mathrm{c}$ is completely surrounded by olivine, with radial fractures that extends well into the surrounding olivine. These fractures are commonly developed and are caused (Wendt et al. 1998) by differential contraction of olivine and chromian spinel upon cooling of the rock. The chromian spinel included in olivine is almost always round or euhedral and does not display the skeletal, planar faces and vermiform texture that are char- acteristic of chromian spinel directly exposed to glass. Where the chromian spinel is only partially included in olivine, it is often lobate or smooth toward the olivine (Figs. 11e-f), but skeletal and zoned toward the glass. Also, chromian spinel shows a tendency toward the vermiform texture in the narrow selvage of glass between olivine and chromian spinel. The chromian spinel completely enclosed in olivine commonly has a lower $\mathrm{Fe}^{2+}$ / $\left(\mathrm{Fe}^{2+}+\mathrm{Mg}\right)$ than chromian spinel exposed to glass.

\section{Cr in glass}

The $\mathrm{Cr}$ content of the glass was carefully measured at least $100 \mu \mathrm{m}$ from the nearest interface with chromian spinel for each sample. The measured $\mathrm{Cr}$ and standard deviation in the glass for the three Icelandic samples are 
373 (SD 30), 380 (SD 40) and 391 (SD 15) ppm. The measured $\mathrm{Cr}$ for the F2 glass is 289 (SD 10) ppm. Electron-microprobe analyses were made of the glass adjacent and at some distance from the chromian spinel crystals. We were particularly interested to determine whether there were variations in the $\mathrm{Cr}$ content of the glass in close proximity $(10-100 \mu \mathrm{m})$ to different parts of the chromian spinel crystals. This could not be verified using the electron microprobe because of significant secondary fluorescence of $\mathrm{Cr}$ in the chromian spinel by $\mathrm{Fe}$ in the glass within $100 \mu \mathrm{m}$ of the chromian spinel crystals. The elements other than $\mathrm{Cr}$ showed no significant variation within $100 \mu \mathrm{m}$ of the chromian spinel.

\section{DisCUSSION}

\section{The amount, size and shape of chromian spinel in basaltic lava}

The chromian spinel in the four lavas described in the present study are larger than is found in most basalts, and there is also a much greater variety of habits. These habits, described as planar, skeletal, dendritic, vermiform and hopper, are in some cases found on one crystal or chain of crystals. The appearance of the texture in two dimensions is very dependent upon the orientation of the section through the crystal. Thus Figures $2 d$ and $10 \mathrm{a}$ are considered to be sections that cut through the vermiform portion of a crystal such as shown in Figures $2 \mathrm{a}$ or 4 . Although the chromian spinel grains found in these four lavas are relatively large, the crystals are still significantly smaller than the accompanying olivine and plagioclase phenocrysts.

The small volume proportion and size of chromian spinel in basaltic lavas have been explained (Hill \& Roeder 1974) by the large difference in solubility of $\mathrm{Cr}$ in chromian spinel and coexisting melt. Thus chromian spinel that contains $30-40$ wt. $\% \mathrm{Cr}_{2} \mathrm{O}_{3}$ can be in equilibrium with a melt that contains only $0.02-0.06$ wt.\% $\mathrm{Cr}_{2} \mathrm{O}_{3}$ (Roeder \& Reynolds 1991). Only a small amount of chromian spinel can crystallize from a melt containing so little $\mathrm{Cr}$, and thus a relatively large volume of melt is necessary in order to crystallize chromian spinel. For example, assuming a ratio of $\mathrm{Cr}$ between chromian spinel and melt of 900 , and assuming that the crystallization of a grain of chromian spinel $10 \mu \mathrm{m}$ in radius reduces the $\mathrm{Cr}$ in the nearby melt by $10 \%$ (e.g., 400 to $360 \mathrm{ppm}$ ), it would take a sphere of melt of approximately $200 \mu \mathrm{m}$ radius to supply the requisite $\mathrm{Cr}$ for the chromian spinel. The distribution coefficients for the other major elements ( $\mathrm{Fe}, \mathrm{Mg}, \mathrm{Al}, \mathrm{Ti}$ ) between chromian spinel and melt are more than two orders of magnitude lower than that for $\mathrm{Cr}$.

\section{Factors that control crystal morphology}

The factors that are important in determining the morphology of crystals that grow from a melt are very complex. Sekerka (1993) has described crystal growth in terms of the three processes, transport, capillarity and interface kinetics. The transport processes include the diffusion of heat and matter to and from the growing crystal, whereas capillarity includes the forces that determine the curvature and relative surface-free energy of the various surfaces of the growing crystal. The term interface kinetics includes those processes that determine the attachment and re-arrangement of molecules and atoms at the crystal interface and are sensitive to step size on the faces. One of the most important factors that controls both the size and shape of chromian spinel in lavas is the very high distribution coefficient of $\mathrm{Cr}$ between chromian spinel and melt. This factor in turn makes crystal size and morphology very dependent on the transport of $\mathrm{Cr}$ from the melt to the growing faces of the crystal.

As stated in the Introduction, chromian spinel in lavas most commonly form 5-20 $\mu$ m octahedra together with the occasional chain of small octahedra where the individual octahedra are attached at corners or edges. Sekerka (1993) described how crystal growth can change from growth on simple rational planes or facets, to growth at corners and edges when a crystal gets to a critical size. For a certain set of conditions, the difference in supersaturation of the melt at the corners and the center of a facet becomes so large as to favor corner growth. Corner or edge growth ultimately produces the chains of chromian spinel grains. Each octahedron of the chain is considered to grow to a certain size until corner growth is favored, and a new octahedron of the chain nucleates. Thus we might expect the octahedra of a chain to grow to a similar size, except where altered by some change in conditions, for example post-extrusion crystallization of groundmass (Bannister et al. 1998). Note that the chromian spinel octahedra in each chain shown in Figure 5 are of a similar size, whereas the octahedra in the chain shown in Figure 6 are of quite different size. Lofgren (1974, 1980), Kirkpatrick (1975) and Donaldson (1976) described how the morphology of plagioclase and olivine changes from planar or tabular growth to skeletal, hopper or dendritic growth as the degree of undercooling increases. They explained this change from planar to edge and corner growth by the increased rate of growth with undercooling and the decreased rate of diffusion in the melt as temperature is lowered.

The single crystals and chains described in the present study are larger and more skeletal than chromian spinel found in most volcanic rocks. We ascribe this difference to the relatively high $\mathrm{Mg}$ content of the lavas (9-10 wt.\% MgO) as compared to most basalts (6-8 wt. \% $\mathrm{MgO}$ ). The higher $\mathrm{Mg}$ content of the melt implies a higher liquidus temperature, decreased viscosity of the melt and more rapid diffusion in the melt. The difference in size of chromian spinel for different lavas must also depend upon significant differences in the cooling regime. For example, the large difference in size of 
chromian spinel in the F2 lava (Fig. 7), compared to the experimental run (Fig. 8) using the same F2 composition, is presumably due to a difference in cooling regime.

The metallurgical and material science literature contain many papers that deal with facet stability and the change from planar to cellular to dendritic growth (e.g., O'Hara et al. 1968, Sekerka 1993, Federov \& Zhivolub 1996). Many of the textural features described in the present study as vermiform are very similar to the cellular growth described for constitutional supercooling of metals and for faceting on quartz and sapphire crystals (O'Hara et al. 1968). We suggest that whereas smaller crystals may respond to supercooling by a change of planar to edge or corner growth, larger planar faces may sometimes respond to increased supercooling by a change to cellular growth, such as that shown in Figures 2 and 4. The cellular growth involves multiple protuberances from the original smooth interface. Thus much of the center of the chromian spinel in Figures 2,4 and $7 \mathrm{~b}, \mathrm{~d}$ are considered to have crystallized fairly rapidly, whereas at a greater degree of supercooling, the growth of the smooth face became unsustainable, and growth proceeded by vermiform or cellular growth. This vermiform or cellular growth was the last stage of growth of the chromian spinel, as it is always found as the outer rim. The faceted vermiform growth seen in Figures $7 \mathrm{~b}$ and $7 \mathrm{~d}$ is consistent with that described by O'Hara et al. (1968) and Kirkpatrick (1975) for cellular growth. The $\mathrm{Cr} /(\mathrm{Cr}+\mathrm{Al})$ of the vermiform rim is usually higher (Fisk \& Bence 1980, present study), but the change in $\mathrm{Cr} /(\mathrm{Cr}+\mathrm{Al})$ is small.

\section{Composition of chromian spinel and of the coexisting melt}

The relationship between the composition of chromian spinel and the melt from which it crystallized at equilibrium has been the focus of many experimental studies (e.g., Hill \& Roeder 1974, Walker et al. 1976, Fisk \& Bence 1980, Maurel \& Maurel 1982a, b, Barnes 1986, Murck \& Campbell 1986, Roeder \& Reynolds 1991). These experimental studies have been used to develop thermodynamic and empirical models to relate the composition of chromian spinel to a melt composition, assuming equilibrium under a certain set of conditions (Sack \& Ghiorso 1991, Allan 1992, Ariskin \& Nikolaev 1996, Poustovetov 2000). The goal has been to use the composition of chromian spinel to infer its past history assuming equilibrium between crystal and melt.

$\mathrm{A} \mathrm{Cr} /(\mathrm{Cr}+\mathrm{Al})$ versus $\mathrm{Fe}^{2+} /\left(\mathrm{Fe}^{2+}+\mathrm{Mg}\right)$ plot of the chromian spinel in the East Pacific Rise lava and the three Icelandic lavas has been shown in Figures 7, 9, 10 and 11 . The temperature for each sample was calculated from the composition of the glass in equilibrium with olivine using the equations of Beattie (1993). Since the array of measured compositions fall within the calculated isopotential curves for the equilibrium between olivine and chromian spinel, and assuming olivine-melt equilibrium in terms of $\mathrm{Fe}^{2+} /\left(\mathrm{Fe}^{2+}+\mathrm{Mg}\right)$, we conclude that the chromian spinel in contact with glass in these four samples is close to apparent $\mathrm{Fe}^{2+} /\left(\mathrm{Fe}^{2+}+\mathrm{Mg}\right)$ equilibrium with the final melt or glass composition (Roeder \& Emslie 1970). It is also obvious, from the varying $\mathrm{Cr} /$ $(\mathrm{Cr}+\mathrm{Al})$ of chromian spinel in the glass for each sample, that these spinel grains could not have grown in equilibrium with the final melt composition. We suggest that the chromian spinel in the glass crystallized from a melt with a $\mathrm{Fe}^{2+} /\left(\mathrm{Fe}^{2+}+\mathrm{Mg}\right)$ close to that of the glass, or, more likely, the $\mathrm{Fe}^{2+} /\left(\mathrm{Fe}^{2+}+\mathrm{Mg}\right)$ of the chromian spinel in contact with glass re-equilibrated with that melt before quenching. The major control on the $\mathrm{Fe}^{2+} /\left(\mathrm{Fe}^{2+}+\mathrm{Mg}\right)$ of the melt was the crystallization of olivine or the mixing of lavas of different composition. Either very little olivine crystallized during crystallization of chromian spinel or, more likely, chromian spinel crystallized together with olivine and the earlierformed chromian spinel exposed to the melt continually re-equilibrated with the changing $\mathrm{Fe}^{2+} /\left(\mathrm{Fe}^{2+}+\mathrm{Mg}\right)$ of the melt. Natland (1989) described compositions of chromian spinel from the East Pacific Rise that showed variable $\mathrm{Cr} /(\mathrm{Cr}+\mathrm{Al})$ but that were essentially parallel to the calculated olivine-spinel isopotential lines of Irvine (1965). Natland suggested that such chromian spinel either crystallized from melts having a narrow range of $\mathrm{Fe}^{2+} /\left(\mathrm{Fe}^{2+}+\mathrm{Mg}\right)$ or as a result of mixing of melts having a similar $\mathrm{Fe}^{2+} /\left(\mathrm{Fe}^{2+}+\mathrm{Mg}\right)$.

Allan (1994) found very large crystals of chromian spinel (up to $2 \mathrm{~mm}$ ) in glass of lavas of the Lau Basin; the chromian spinel having a very high $\mathrm{Cr} /(\mathrm{Cr}+\mathrm{Al})$ value, 0.7 , shows a large increase in $\mathrm{Fe}^{2+} /\left(\mathrm{Fe}^{2+}+\mathrm{Mg}\right)$ from core to rim without change in $\mathrm{Cr} /(\mathrm{Cr}+\mathrm{Al})$. Allan suggested that the $\mathrm{Fe}^{2+} /\left(\mathrm{Fe}^{2+}+\mathrm{Mg}\right)$ of the chromian spinel partially equilibrated with the melt, but the trivalent cations were unable to re-equilibrate with the melt in the available time. The data of the present study support this observation. The chromian spinel completely enclosed in olivine commonly has a lower $\mathrm{Fe}^{2+} /\left(\mathrm{Fe}^{2+}+\right.$ $\mathrm{Mg}$ ); it is reasonable to assume that some of the chromian spinel in contact with glass was present when the chromian spinel in olivine was formed. Thus only chromian spinel protected by olivine did not change its $\mathrm{Fe}^{2+} /\left(\mathrm{Fe}^{2+}+\mathrm{Mg}\right)$. The change in $\mathrm{Fe}^{2+} /\left(\mathrm{Fe}^{2+}+\mathrm{Mg}\right)$ of chromian spinel in glass occurred in response to a changing composition of the melt primarily because of olivine crystallization or magma mixing.

We have attributed the variety of growth forms in these lavas to kinetic processes. Thus it is also reasonable to assume that some of the variation in $\mathrm{Cr} / \mathrm{Cr}+$ $\mathrm{Al}$ ) of the chromian spinel might also be due to kinetic processes (Thy 1983, Allan et al. 1988). We have not seen any evidence of significant variation of glass composition within any of these lavas. If complete equilibrium had been established, all chromian spinel in the glass should have the same $\mathrm{Cr} /(\mathrm{Cr}+\mathrm{Al})$. If the transport of $\mathrm{Cr}$ to the growing crystals were a rate-controlling variable that influenced both the morphology and 
composition of the chromian spinel, then the chromian spinel with the lowest $\mathrm{Cr} /(\mathrm{Cr}+\mathrm{Al})$ would not be expected to have grown in equilibrium with the bulk composition of the melt.

\section{Zoning in crystals of chromian spinel}

The variation of $\mathrm{Cr} /(\mathrm{Cr}+\mathrm{Al})$ in the chromian spinel in the four lavas is significant both within and between crystals. This zoning may be due to magma mixing (Allan et al. 1988, 1989), fractional crystallization, kinetic factors (Thy 1983, Longhi et al. 1993) or, more likely, some combination of these processes. We believe that some of the $\mathrm{Cr} /(\mathrm{Cr}+\mathrm{Al})$ zoning is due to a variation in rate of growth in response to the degree of supercooling and to the rate of transport of $\mathrm{Cr}$ to the growing crystal. The changing rate of crystal growth was most likely due to thermal perturbations, but it may also have been due to changing liquidus temperature because of small changes of pressure and loss of volatile components (Hort 1997, 1998), or by magma mixing. The zoning in the chromian spinel is in some cases oscillatory, indicating turbulence and disruption of the boundary layer surrounding the chromian spinel. Oscillatory zoning also may have resulted from complex interaction between the rate of crystal growth and rate of diffusion through the boundary layer. The factors that are important in describing diffusion-controlled crystallization, such as diffusion coefficients in the melt, distribution coefficients of elements between crystal and melt, and rate of crystal growth have been addressed in equations developed by Albarède \& Bottinga (1972) and Lasaga (1981). There are, however, too many unknown factors to be able to quantify the processes that led to the zoning described in the present study.

The maximum extent of $\mathrm{Cr} /(\mathrm{Cr}+\mathrm{Al})$ zoning of chromian spinel for the four lavas is almost 0.30 , found in the $\mathrm{F} 2$ samples (Fig. 7). The $\mathrm{Cr} /(\mathrm{Cr}+\mathrm{Al})$ zoning in the F2 lavas is significantly greater than that for the other three lavas. The F2 lavas are also different in that they contain a significant number of plagioclase phenocrysts that are filled with melt inclusions and contain growth forms indicative of rapid growth (Kuritani 1999). Thus the cooling regime of this sample may have been more extreme than that for the other samples. We also suggest that given the relative difficulty of nucleating new crystals of plagioclase (Longhi 1992), the melt adjacent to crystals of chromian spinel may have become supersaturated with respect to plagioclase upon lowering temperature, or changing liquidus temperature, and the chromian spinel became much more aluminous than that assuming local equilibrium crystallization. Thus the $\mathrm{Cr} /$ $(\mathrm{Cr}+\mathrm{Al})$ zoning in chromian spinel may have been accentuated by the lack of local nucleation of plagioclase. Allan et al. $(1988,1989)$ explained much of the textural and chemical complexities in the F2 samples as due to magma mixing between an evolved melt containing high- $\mathrm{Cr} /(\mathrm{Cr}+\mathrm{Al})$ chromian spinel and a more primi- tive melt with lower- $\mathrm{Cr} /(\mathrm{Cr}+\mathrm{Al})$ chromian spinel. This hypothesis does not explain, however, the distinctly lower $\mathrm{Ti}$ and $\mathrm{Fe}^{3+}$ in most chromian spinel with a high $\mathrm{Cr} /(\mathrm{Cr}+\mathrm{Al})$ value in sample $\mathrm{F} 2$ as compared with chromian spinel from the more evolved samples.

\section{Petrological implications of morphology and zoning of chromian spinel}

The use of textural criteria to explain magmatic processes is fraught with danger because many of the descriptions and arguments are qualitative. Thus a texture such as that shown in Figures 2, 4 and 10h had previously been interpreted as a reaction texture, whereas we have interpreted it as a growth texture. This difference in interpretation also extends to whether the $\mathrm{Cr} / \mathrm{Cr}+$ $\mathrm{Al}$ ) zoning in chromian spinel is due to variation in the bulk composition of the melt or, as we contend, due in part to very local (micrometer scale) diffusion-controlled crystallization that accompanies variation in degree of supercooling.

The solid curves shown in Figure 3 represent the common trends of changing composition of chromian spinel in basaltic and andesitic lavas. The $P-X$ trend represents the change expected in chromian spinel if the crystallization of olivine significantly increases the $\mathrm{Fe}^{2+}$ / $\left(\mathrm{Fe}^{2+}+\mathrm{Mg}\right)$ of the melt. The evidence for this trend in the present study is the lower $\mathrm{Fe}^{2+} /\left(\mathrm{Fe}^{2+}+\mathrm{Mg}\right)$ of chromian spinel completely enclosed within olivine as compared to chromian spinel in contact with glass. The position and extent of the $X-Y$ trend in Figure 3 have been drawn consistent with the olivine $\left(\mathrm{Fo}_{89}\right)-$ chromian spinel equipotential curve for the chromian spinel in the F2 lava, which is the most primitive, having the lowest $\mathrm{Fe}^{2+} /\left(\mathrm{Fe}^{2+}+\mathrm{Mg}\right)$ of the four lavas. The large range of $\mathrm{Cr} /(\mathrm{Cr}+\mathrm{Al})$ in the chromian spinel of a single lava, $X-Y$ for sample $\mathrm{F} 2$, is striking when compared to the range found for all the MORB samples (Fig. 3). The $X-Y$ trend of variable $\mathrm{Cr} /(\mathrm{Cr}+\mathrm{Al})$ at approximately constant $\mathrm{Fe}^{2+} /\left(\mathrm{Fe}^{2+}+\mathrm{Mg}\right)$ of the melt could be attributed to diffusion-controlled crystallization of chromian spinel, fractional crystallization of plagioclase or chromian spinel, or to mixing a more primitive melt with a more evolved melt of equal $\mathrm{Fe}^{2+} /\left(\mathrm{Fe}^{2+}+\mathrm{Mg}\right)$. Thus the change in $\mathrm{Cr} /(\mathrm{Cr}+\mathrm{Al})$ of chromian spinel could represent only a very local change in melt composition due to growth of chromian spinel or to a more general change in magma composition. Although the chromian spinel may have a composition that now lies along an $X-Y$ trend, it may have partially formed at lower values of $\mathrm{Fe}^{2+} /\left(\mathrm{Fe}^{2+}+\mathrm{Mg}\right)$ but continually re-equilibrated its $\mathrm{Fe}^{2+} /\left(\mathrm{Fe}^{2+}+\mathrm{Mg}\right)$ with the melt before quenching. Repeated turbulence and disruption of the melt boundarylayer around chromian spinel and changing growth-rate may produce what appears to be oscillatory zoning.

The $R-S$ and $T-V$ trends on Figure 3 are not seen in the samples used in the present study because these trends are only found in lavas that cooled relatively 
slowly. The $R-S$ trend is very common for chromian spinel in volcanic rocks (Roeder 1994) and is considered to result from simultaneous crystallization of plagioclase and olivine, commonly due to groundmass crystallization (Bannister et al. 1998). The experimental run using the $\mathrm{F} 2$ composition resulted in significant crystallization of olivine and plagioclase, which produced the $R-S$ trend in chromian spinel (dashed line in Fig. 7). Once pyroxene crystallizes and removes $\mathrm{Cr}$ from the melt, the chromian spinel changes composition along a trend similar to $T-U$ (Fig. 3) toward magnetite, with a low $\mathrm{Cr} /(\mathrm{Cr}+\mathrm{Al})$, or at some stage the spinel phase becomes unstable and ceases to crystallize (Hill $\&$ Roeder 1974).

The large difference in $\mathrm{Cr} /(\mathrm{Cr}+\mathrm{Al})$ of chromian spinel in zones within $5 \mu \mathrm{m}$ of each other suggests that the crystals of chromian spinel in the lava could not have remained very long at the high temperatures (1150$1225^{\circ} \mathrm{C}$ ) at which the chromian spinel formed. There are no reliable quantitative data on the magnitude of the diffusion coefficients for $\mathrm{Cr}$ and $\mathrm{Al}$ in chromian spinel at magmatic temperatures. However, from experience observing experimental runs, we conclude that the sharp $\mathrm{Cr} /(\mathrm{Cr}+\mathrm{Al})$ discontinuity seen in some crystals could not have been maintained for many hours before quenching. This conclusion also implies that the chromian spinel crystallized over a relatively short timeinterval. We have concluded that diffusion-controlled crystallization was responsible for the variety of growth forms and may also have been responsible for some of the zoning of the crystals. The relatively rapid diffusion of species in the basaltic melt (assuming $\mathrm{D}$ in the range $10^{-6}-10^{-8} \mathrm{~cm}^{2} / \mathrm{s}$ at $1200^{\circ} \mathrm{C}$ ) leads to the conclusion that the growth of some of these crystals probably happened over a time span of hours to a few days. This inference is consistent with the much smaller growthforms found in chromian spinel in the experimental run, which was cooled over 8 hours from $1225^{\circ} \mathrm{C}$ to $1147^{\circ} \mathrm{C}$.

It has been suggested that some of the variation in $\mathrm{Cr} /(\mathrm{Cr}+\mathrm{Al})$ of the chromian spinel may be due to kinetic factors, and not to changes in the bulk composition of the melt. If this explanation is correct, then it is necessary to re-evaluate the role of zoning as a petrogenetic indicator of changing bulk-composition of the melt or changing total pressure. Although the zoning in terms of $\mathrm{Cr} /(\mathrm{Cr}+\mathrm{Al})$ in chromian spinel may not be as useful in evaluating changing bulk-composition of the melt, it may, in the future, enable petrologists to better understand the immediate pre-eruption thermal and compositional history of basaltic lavas. Knowledge of the differential diffusion-coefficients for $\mathrm{Cr}$ and $\mathrm{Al}$, and $\mathrm{Fe}$ and $\mathrm{Mg}$, in both basaltic melt and in chromian spinel, should enable petrologists to estimate the maximum time needed for the crystals to grow and the maximum time that the crystals remained at close to liquidus temperatures before quenching, using equations similar to those developed by Albarède \& Bottinga (1972) and Lasaga (1981).
According to our interpretation of the crystallization of chromian spinel in these lavas, there are three fairly distinctive textural modes of chromian spinel that can be placed in a temporal sequence. The earliest period (A) is represented by the crystallization of olivine and relatively small euhedra of chromian spinel under fairly stable thermal conditions from a magma of lower $\mathrm{Fe}^{2+}$ / $\left(\mathrm{Fe}^{2+}+\mathrm{Mg}\right)$ than the glass. The lines of evidence for this period are the lower $\mathrm{Fe}^{2+} /\left(\mathrm{Fe}^{2+}+\mathrm{Mg}\right)$ of the chromian spinel within magnesian olivine and the high $\mathrm{Cr} /(\mathrm{Cr}+\mathrm{Al})$ core (A) of crystals, such as shown in Figures $2 a, b$ and $7 \mathrm{a}$. The second period (B) is one of rapid growth of both olivine and chromian spinel, leading to large skeletal and zoned olivine and chromian spinel, which is interpreted to reflect the period when the magma is moving toward the Earth's surface. An example of simultaneous growth of olivine and chromian spinel during stage $\mathrm{B}$ is shown in Figure 2c. The crystallization of olivine increases the $\mathrm{Fe}^{2+} /\left(\mathrm{Fe}^{2+}+\mathrm{Mg}\right)$ of the magma and of the chromian spinel crystals. It is during this period of fairly rapid growth and zoning to a lower $\mathrm{Cr} /(\mathrm{Cr}+\mathrm{Al})$ that the cores such as B in Figure 2 are formed. Some cores (Fig. 4) have holes, which reflect relatively rapid growth of hopper-like crystals. The third period is one of a change in the rate and style of growth, leading to the vermiform rim (C in Fig. 2). We believe that this stage results from the breakdown of the relatively smooth interface between chromian spinel and melt to a type of cellular growth because diffusion in the melt is no longer able to support growth of a smooth interface. This change in growth rate may happen when the magma is relatively close to, or on, the Earth's surface. The third period, involving vermiform growth (C) may be due to a greater undercooling of the melt, and is the last period of growth before quenching. All three zones of chromian spinel may re-equilibrate in terms of $\mathrm{Fe}^{2+} /\left(\mathrm{Fe}^{2+}+\mathrm{Mg}\right)$ with the last melt, depending upon the shape of the crystals, the proximity and local mixing of melt and the length of time exposed to that melt.

The variation in composition of chromian spinel in lavas can give valuable information about the changing state of the whole magma due to processes such as differentiation and magma mixing. However, it is also important to consider the effect of local environment around the chromian spinel and kinetic processes, such as diffusion-controlled crystallization. The usefulness of the morphology and composition of chromian spinel as a petrogenetic indicator also applies to chromian spinel that crystallizes fairly rapidly in chondrules from meteorites (Ramdohr 1973, Jones 1990, Johnson \& Prinz 1991, McCoy et al. 1991, Krot et al. 1993) and in kimberlites (Pasteris 1983, Armstrong et al. 1997). Although the crystals of chromian spinel are very small and few in number, this mineral has much to tell us about the magmatic history of a sample. This statement also applies to the much larger skeletal crystals of chromian spinel that have been reported (Greenbaum 
1977, Christiansen \& Olesen 1990) from podiform chromitites associated with ophiolites.

\section{Conclusions}

The four MORB lavas considered in the present study are unique in the variety of growth forms of the chromian spinel, the relatively large size of the crystals compared to those in most basaltic lavas, and the large range in their $\mathrm{Cr} /(\mathrm{Cr}+\mathrm{Al})$ values. The four lavas are also distinctive in that the $\mathrm{Mg}$ content of the glass is high compared to other basalts, and thus the temperature was relatively high and the viscosity relatively low. The textural and compositional variability of the chromian spinel in these lavas is mainly the result of relatively rapid crystallization over a few hours to days before eruption. We contend that the chromian spinel shows a large variation in $\mathrm{Cr} /(\mathrm{Cr}+\mathrm{Al})$ in part because of diffusion-controlled crystallization due to the large difference in distribution coefficient of $\mathrm{Al}$ and $\mathrm{Cr}$ between chromian spinel and melt. It is not possible, however, to say how much of the variability in the $\mathrm{Cr} /(\mathrm{Cr}+$ $\mathrm{Al}$ ) of chromian spinel in these samples is due to diffusion-controlled crystallization and how much is due to mixing of magmas just prior to eruption or fractional crystallization of the phenocryst phases. During the time that the chromian spinel crystallized there was a change in the $\mathrm{Fe}^{2+} /\left(\mathrm{Fe}^{2+}+\mathrm{Mg}\right)$ of the bulk melt due to olivine crystallization; the chromian spinel in contact with melt re-equilibrated, leading to changes in $\mathrm{Fe}^{2+} /\left(\mathrm{Fe}^{2+}+\mathrm{Mg}\right)$. This reconstruction is confirmed by the close correspondence of the composition of chromian spinel to the calculated olivine-spinel "equipotential" curves on the graphs of $\mathrm{Cr} /(\mathrm{Cr}+\mathrm{Al})$ versus $\mathrm{Fe}^{2+} /\left(\mathrm{Fe}^{2+}+\mathrm{Mg}\right)$. The presence of chains of chromian spinel in these and other basaltic lavas is another indication of the common tendency for diffusion-controlled crystallization of chromian spinel in lavas.

\section{ACKNOWLEDGEMENTS}

We thank James F. Allan (U.S. National Science Foundation) for donating the East Pacific Rise samples and for his review of the manuscript. We also thank an anonymous reviewer and Robert F. Martin for their constructive comments on the manuscript. Susan Humphris (Woods Hole Oceanographic Institution), Haraldur Sigurdsson (Graduate School of Oceanography, University of Rhode Island) and Carl Thornber (United States Geological Survey) are thanked for donating samples of basalt that were used in this study. We are indebted to David Kempson for maintaining the electron microprobe and for his help with analytical procedures. We thank Joan Charbonneau and Ellen Mulder for their help with the manuscript. Financial support was provided by the Natural Sciences and Engineering Research Council of Canada.

\section{REFERENCES}

Albarède, F. \& Bottinga, Y. (1972): Kinetic disequilibrium in trace element partitioning between phenocrysts and host lava. Geochim. Cosmochim. Acta 36, 141-156.

Allan, J.F. (1992): Cr-spinel as a petrogenetic indicator: deducing magma composition from spinel in highly altered basalts from the Japan Sea, Sites 794 and 797. Proc. Ocean Drilling Program 127/128, 837-847.

(1994): Cr-spinel in depleted basalts from the Lau Basin backarc: petrogenetic history from $\mathrm{Mg}-\mathrm{Fe}$ crystalliquid exchange. Proc. Ocean Drilling Program 135, 565583.

Batiza, R., Perfit, M.R., Fornari, D.J. \& SACK, R.O. (1989): Petrology of lavas from the Lamont seamount chain and adjacent East Pacific Rise, $10^{\circ}$ N. J. Petrol. 30, 1245-1298.

Falloon, T., Pedersen, R.B., Lakkapragada, B.S., Natland, J.H. \& Malpas, J. (1996): Petrology of selected Leg 147 basaltic lavas and dikes. Proc. Ocean Drilling Program 147, 173-185.

SACK, R.O. \& BATIZA, R. (1988): Cr-rich spinels as petrogenetic indicators: MORB-type lavas from the Lamont seamount chain, eastern Pacific. Am. Mineral. 73, 741-753.

Ariskin, A.A. \& Nikolaev, G.S. (1996): An empirical model for the calculation of spinel-melt equilibria in mafic igneous systems at atmospheric pressure. 1. Chromian spinels. Contrib. Mineral. Petrol. 123, 282-292.

Armstrong, K.A., Roeder, P.L. \& Helmstaedt, H.H. (1997): Composition of spinels in the C14 kimberlite, Kirkland Lake, Ontario. Russ. Geol. Geophys. 38, 454-466.

Bannister, V., Roeder, P.L. \& Poustovetov, A. (1998): Chromite in the Paricutin lava flows (1943-1952). J. Volcanol. Geotherm. Res. 87, 151-171.

BARNES, S.J. (1986): The distribution of chromium among orthopyroxene, spinel and silicate liquid at atmospheric pressure. Geochim. Cosmochim. Acta 50, 1889-1909.

Beattie, P. (1993): Olivine-melt and orthopyroxene-melt equilibria. Contrib. Mineral. Petrol. 115, 103-111.

Brandon, A.D. \& Draper, D.S. (1996): Constraints on the origin of the oxidation state of mantle overlying subduction zones: an example from Simcoe, Washington, USA. Geochim. Cosmochim. Acta 60, 1739-1749.

BRYAN, W.B. (1972): Morphology of quench crystals in submarine basalts. J. Geophys. Res. 77, 5812-5819.

\& Moore, J.G. (1977): Compositional variations of young basalts in the Mid-Atlantic Ridge rift valley near lat. $36^{\circ} 49^{\prime}$ N. Geol. Soc. Am., Bull. 88, 556-570. 
Christiansen, F.G. \& Olesen, N.O. (1990): Large skeletal chromites in the Vourinos ophiolite, Greece. Geol. Soc. Denmark, Bull. 38, 33-42.

DiCK, H.J.B. \& BRYAN, W.B. (1978): Variation of basalt phenocryst mineralogy and rock compositions in DSDP Hole 396B. Initial Rep., Deep-Sea Drilling Project 46, 215225.

\& Bullen, T. (1984): Chromian spinel as a petrogenetic indicator in abyssal and alpine-type peridotites and spatially associated lavas. Contrib. Mineral. Petrol. 86, 54-76.

Donaldson, C.H. (1976): An experimental investigation of olivine morphology. Contrib. Mineral. Petrol. 57, 187-213.

Fedorov, O.P. \& Zhivolub, E.L. (1996): Crystallization front structure during growth of single crystals from a melt in various crystallographic directions. Growth of Crystals 20, 139-151.

Fisk, M.R. \& BeNCE, A.E. (1980): Experimental crystallization of chromite spinel in FAMOUS basalt 527-1-1. Earth Planet. Sci. Lett. 48, 111-123.

Furuta, T. \& Tokuyama, H. (1983): Chromian spinels in Costa Rica Rift basalts, Deep Sea Drilling Project Site 505 - a preliminary interpretation of electron microprobe analyses. Initial Rep., Deep-Sea Drilling Project 69, 805-810.

Gaetani, G.A., DeLong, S.E. \& Wark, D.A. (1995): Petrogenesis of basalts from the Blanco Trough, northeast Pacific: inferences for off-axis melt generation. J. Geophys. Res. 100, 4197-4214.

Graham, A.L., Symes, R.F., Bevan, J.C. \& Din, V.K. (1979): Chromium-bearing spinels in some rocks of Leg 45: phase chemistry, zoning and relation to host basalt chemistry. Initial Rep., Deep-Sea Drilling Project 45, 581-586.

Greenbaum, D. (1977): The chromitiferous rocks of the Troodos ophiolite complex, Cyprus. Econ. Geol. 72, 11751194.

Hansteen, T.H. (1991): Multi-stage evolution of the picritic Mælifell rocks, SW Iceland: constraints from mineralogy and inclusions of glass and fluid in olivine. Contrib. Mineral. Petrol. 109, 225-239.

Hardardottir, V. (1986): The petrology of the Mælifell picrite basalt, southern Iceland. Jökull. 36, 31-40.

HiLl, R. \& RoEdeR, P.L. (1974): The crystallization of spinel from basaltic liquid as a function of oxygen fugacity. $J$. Geol. 82, 709-729.

HoRT, M. (1997): Crystallization processes in response to abrupt liquidus temperature changes. Trans. Am. Geophys. Union 78, F794 (abstr.)

(1998): Abrupt change in magma liquidus temperature because of volatile loss or magma mixing: effects on nucleation, crystal growth and thermal history of the magma. J. Petrol. 39, 1063-1076.

IRVINE, T.N. (1965): Chromian spinel as a petrogenetic indicator. I. Theory. Can. J. Earth Sci. 2, 648-672.

Johnson, C.A. \& Prinz, M. (1991): Chromite and olivine in type II chondrules in carbonaceous and ordinary chondrites: implications for thermal histories and group differences. Geochim. Cosmochim. Acta 55, 893-904.

JoNES, R.H. (1990): Petrology and mineralogy of Type II, FeOrich chondrules in Semarkona (LL3.0): origin by closedsystem fractional crystallization, with evidence for supercooling. Geochim. Cosmochim. Acta 54, 1785-1802.

KIRKPATRICK, R.J. (1975): Crystal growth from the melt: a review. Am. Mineral. 60, 798-814.

Krot, A., Ivanova, M.A. \& Wasson, J.T. (1993): The origin of chromitic chondrules and the volatility of $\mathrm{Cr}$ under a range of nebular conditions. Earth Planet. Sci. Lett. 119, $569-584$

KURITANI, T. (1999): Phenocryst crystallization during ascent of alkali basalt magma at Rishiri Volcano, northern Japan. J. Volcanol. Geotherm. Res. 88, 77-97.

LASAGA, A.C. (1981): Implications of a concentration-dependent growth rate on the boundary layer crystal-melt model. Earth Planet. Sci. Lett. 56, 429-434.

LOFGREN, G.E. (1974): Temperature induced zoning in synthetic plagioclase feldspar. In The Feldspars (W.S. MacKenzie \& J. Zussman, ed.). Manchester University Press, Manchester, England (362-375).

(1980): Experimental studies on the dynamic crystallization of silicate melts. In Physics of Magmatic Processes (R.B. Hargraves, ed.). Princeton University Press, Princeton, N.J. (487-551).

LONGHI, J. (1992): Experimental petrology and petrogenesis of Mare volcanics. Geochim. Cosmochim. Acta 56, 22352251.

Fram, M.S., Auwera, J.V. \& Montieth, J.N. (1993): Pressure effects, kinetics, and rheology of anorthositic and related magmas. Am. Mineral. 78, 1016-1030.

Maurel, C. \& Maurel, P. (1982a): Etude expérimentale de la distribution de l'aluminium entre bain silicaté basique et spinelle chromifère. Implications pétrogénétiques: teneur en chrome des spinelles. Bull. Minéral. 105, 197-202.

$\&$ (1982b): Etude expérimentale de la solubilité du chrome dans les bains silicatés basiques et de sa distribution entre liquide et minéraux coexistants: conditions d'existence du spinelle chromifère. Bull. Minéral. 105, 640-647.

McCoy, T.J., Pun, A. \& KeIL, K. (1991): Spinel-bearing, Alrich chondrules in two chondrite finds from Roosevelt 
County, New Mexico: indicators of nebular and parent body processes. Meteoritics 26, 301-309.

Murck, B.W. \& CAmpBell, I.H. (1986): The effects of temperature, oxygen fugacity and melt composition on the behaviour of chromium in basic and ultrabasic melts. Geochim. Cosmochim. Acta 50, 1871-1887.

NATLAND, J.H. (1989): Partial melting of a lithologically heterogeneous mantle: inferences from crystallization histories of magnesian abyssal tholeiites from the Siqueiros Fracture Zone. In Magmatism in the Ocean Basins (A.D. Saunders \& M.J. Norry, eds.). Geol. Soc., Spec. Publ. 42 41-70.

O'Hara, S., TARshis, L.A., TILler, W.A. \& Hunt, J.P. (1968): Discussion of interface stability of large facets on solution grown crystals. J. Crystal Growth 3-4, 555-561.

PASTERIS, J.D. (1983): Spinel zonation of the De Beers kimberlite, South Africa: possible role of phlogopite. Can. Mineral. 21, 41-58.

Poustovetov, A. (2000): Numerical Modeling of Chemical Equilibria Between Chromian Spinel, Olivine, and Basaltic Melt, with Petrologic Applications. Ph.D. thesis, Queen's Univ., Kingston, Ontario.

RAmdohr, P. (1973): The Opaque Minerals in Stony Meteorites. Elsevier, Amsterdam, The Netherlands.

Roeder, P.L. (1994): Chromite: from the fiery rain of chondrules to the Kilauea Iki lava lake. Can. Mineral. 32, 729-746.

\& EMSLIE, R.F. (1970): Olivine-liquid equilibrium. Contrib. Mineral. Petrol. 29, 275-289.

\& REYNOLDS, I. (1991): Crystallization of chromite and chromium solubility in basaltic melts. J. Petrol. 32, 909-934.
SACK, R.O. \& GHIORSO, M.S. (1991): Chromian spinels as petrogenetic indicators: thermodynamics and petrologic applications. Am. Mineral. 76, 827-847.

SEKERKA, R.F. (1993): Role of instabilities in determination of the shapes of growing crystals. J. Crystal Growth 128, 112 .

Sigurdsson, H. (1977): Spinels in Leg 37 basalts and peridotites: phase chemistry and zoning. Initial Rep., DeepSea Drilling Project 3, 883-891.

\& SCHILling, J.-G. (1976): Spinels in Mid-Atlantic Ridge basalts: chemistry and occurrence. Earth Planet. Sci. Lett. 29, 7-20.

Thy, P. (1983): Spinel minerals in transitional and alkali basaltic glasses from Iceland. Contrib. Mineral. Petrol. 83, 141-149.

Tronnes, R.G. (1990): Basaltic melt evolution of the Hengill volcanic system, SW Iceland, and evidence for clinopyroxene assimilation in primitive tholeiitic magmas. $J$. Geophys. Res. 95, 15893-15910.

Walker, D., KirkPatrick, R.J., LONGhi, J. \& Hays, J.F. (1976): Crystallization history of lunar picrite basalt sample 12002: phase equilibria and cooling-rate studies. Geol. Soc. Am., Bull. 87, 646-656.

Wendt, A.S., Altenberger, U. \& D'Arco, P. (1998): Radiating cracks around chromite inclusions in olivine: constraints on P-T histories based on the thermoelastic properties of minerals. Schweiz. Mineral. Petrogr. Mitt. 78, 365-374.

Wilcox, R.E. (1954): Petrology of Paricutín volcano, Mexico. U.S. Geol. Surv., Bull. 965-C, 281-353.

Received October 1, 1999, revised manuscript accepted July 17, 2000. 